(C) 2020, The Authors. Published by FASS Inc. and Elsevier Inc. on behalf of the American Dairy Science Association ${ }^{\circledR}$. This is an open access article under the CC BY-NC-ND license (http://creativecommons.org/licenses/by-nc-nd/4.0/).

\title{
Prevalence of methicillin-resistant (mecA gene) and heat-resistant Staphylococcus aureus strains in pasteurized camel milk
}

\author{
Hany M. Yehia, ${ }^{1,2 *}$ ๑ Abdulrahman H. Al-Masoud, ${ }^{1}$ Khaloud M. Alarjani, ${ }^{3} \odot$ and Mohamed S. Alamri ${ }^{1}$ \\ ${ }^{1}$ Food Science and Nutrition Department, College of Food and Agricultural Sciences, King Saud University, P.O. Box 2460, Riyadh 11451, \\ Saudi Arabia \\ ${ }^{2}$ Food Science and Nutrition Department, Faculty of Home Economics, Helwan University, P.O. Box 11611, Cairo, Egypt \\ ${ }^{3}$ Department of Botany and Microbiology, College of Science, King Saud University, P.O. Box 2455, Riyadh 11451, Saudi Arabia
}

\begin{abstract}
Staphylococcus aureus is a significant opportunistic pathogen in humans, dairy cattle, and camels. The presence of antibiotic-resistant and heat-resistant bacteria in camel milk has become a potential public health issue. The phenotypic and molecular characterization of methicillin-resistant staphylococcal strains recovered from pasteurized camel milk distributed in retail markets of Saudi Arabia was assessed. A total of 100 samples were collected between March and May 2017. Out of the $20 \mathrm{~S}$. aureus isolates that were recovered from the pasteurized camel milk, 10 were found to be resistant to cefoxitin $(30 \mu \mathrm{g})$ and, thus, were designated as methicillin-resistant strains. The resistance ratio of methicillin-resistant $S$. aureus isolates for a different class of antibiotics was determined by performing the antimicrobial susceptibility test and was estimated to be approximately $60 \%$. Polymerase chain reaction assay was performed to amplify the methicillin-resistant gene $m e c A$, and furthermore, nucleotide sequencing was performed to detect and verify the presence of methicillin-resistant strains. Upon sequencing the putative S. aureus methicillin-resistant strains, we obtained 96 to $100 \%$ similarity to the penicillin-binding protein $2 \mathrm{a}$ gene (mecA) of the S. aureus strain CS100. Moreover, the 10 methicillin-resistant $S$. aureus isolates were also identified to be heat resistant and were stable at temperatures up to $85^{\circ} \mathrm{C}$ for $60 \mathrm{~s}$, with 3 isolates being heat resistant even at $90^{\circ} \mathrm{C}$ for 60 or $90 \mathrm{~s}$. The mean decimal reduction time $\left(\mathrm{D}_{85}\right.$ value) was $111 \mathrm{~s}$ for all the 10 isolates. No difference was observed in the profile of total protein between the 10 methicillin- and heat-resistant $S$. aureus isolates and the $S$. aureus strain ATCC 29737, which was determined by sodium dodecyl sulfate-PAGE analyses. Therefore, we could conclude that a relatively high percentage of the tested pasteurized camel milk
\end{abstract}

Received September 24, 2019.

Accepted March 2, 2020.

*Corresponding author: hanyehia@ksu.edu.sa samples were contaminated with S. aureus (20\%) and methicillin- and heat-resistant S. aureus (10\%).

Key words: methicillin-resistant Staphylococcus aureus, pasteurized camel milk, PCR, mecA gene, D-value

\section{INTRODUCTION}

Foodborne pathogens include numerous bacterial species that can potentially cause food poisoning, such as Staphylococcus aureus, and are responsible for opportunistic, nosocomial, and community-associated disease outbreaks worldwide (Paterson et al., 2014). Some strains of bacteria that belong to the genus Staphylococcus are found to be resistant to different antibiotics, including methicillin. Methicillin-resistant S. aureus (MRSA) strains contain mecA, a gene that encodes for the penicillin-binding protein 2a (PBP2a), which induces resistance to methicillin and other $\beta$-lactam antibiotics, making them a global public health concern (Arsic et al., 2012). The widespread distribution of these strains is likely because of the extensive use of antibiotics to treat humans against different microorganisms, and in veterinary medicine for treating animals. The antibiotics have also been used for food treatments, even though it is known to be illegal and internationally forbidden in European countries, where substantial research in antibiotic resistance has been carried out and antibiotic use for growth promotion has been prohibited for more than a decade (Founou et al., 2016). Methicillin-resistant S. aureus has also been established in livestock, which was previously linked to the transmission from humans to animals (Voss et al., 2005). Moreover, the prevalence of MRSA in livestock has increased over time, which results in contaminated food products. Staphylococcus aureus is considered to be one of the most important infectious etiological agents that is responsible for causing mastitis in dairy cattle (Moon et al., 2007; Nam et al., 2011). A large number of antibiotics, which are commercially available and approved by the US Food and Drug Ad- 
ministration (FDA, 2011), are being used for treating mastitis in dairy cattle. These antibiotics are divided into 2 classes of antimicrobials: first, $\beta$-lactams (e.g., penicillin, amoxicillin, cloxicillin, ceftiofur, hetacillin, and cephapirin), and, second, lincosamides (e.g., pirlimycin). Although the antibiotic methicillin is not being used for the treatment of mastitis, MRSA strains have still been isolated from cattle milk. Song et al. (2016) isolated MRSA from the milk of cattle that were suffering from mastitis. Moreover, the presence of MRSA in the environment might be a potential source for MRSA infection in animals because these bacteria are capable of surviving in a dormant stage for several months (Lim et al., 2013). Many different strains of MRSA are being identified to be responsible for nosocomial infections and thus, have a significant effect on the patients. The prevalence here is defined as the proportion of MRSA found in the total number of samples/population of $S$. aureus. The bigger the sample number, the more accurate is the estimation of prevalence. Food contamination is mainly caused by incorrect handling of food, which also involves illegal transport by passengers on international flights, and borders have been previously identified as major route for the transmission of many different antibiotic-resistant strains, especially bacterial strains, such as MRSA (Rodríguez-Lázaro et al., 2017). Contaminated food of animal origin might also contribute to the incidence of community-associated MRSA (CA-MRSA; Ogata et al., 2012; Rodríguez-Lázaro et al., 2015), or hospital-acquired MRSA (Pu et al., 2009; Weese et al., 2010). Macori et al. (2017) revealed the presence of multiple MRSA strains among the farm animals, which was further associated with possible human contaminations. Macori et al. (2017) also found that 11 of the mecA-positive strains that were confirmed by PCR (out of 27 strains in total) indicated a human host origin using the biotyping experiment. The 5 strains that were isolated from the operators (through nasal swabs, oral swabs, and skin swabs) of the 2 farms ( 3 and 4) were considered as the common infectious agents for the individual milk samples (3 isolates), bulk tank milk samples (2 isolates), and ovine swab skin (1 isolate). Human migration aids to the rapid spread of MRSA, which itself has reached a level that was never seen before in the history of humankind. Methicillin-resistant $S$. aureus has successfully adapted to the environment and the conditions that humans have created, and thus, these microbes have thrived (Bal et al., 2016).

For the 3 categories of MRSA, including CA-MRSA, hospital-acquired MRSA, and potentially livestock-acquired MRSA, transmission through international travelers was a major possibility. However, current evidence is largely restricted to case studies and case reports, whereas systematic research on imported MRSA and, most importantly, on the effectiveness of the potential interventions for these containments, is very limited. Individuals may acquire MRSA either during leisure traveling or healthcare exposure overseas, resulting in either asymptomatic colonization or clinically significant MRSA disease. Newly imported MRSA strains may potentially replace the native strains of MRSA as the dominant strains, thus resulting in potential outbreaks within the community or in healthcare settings (Zhou et al., 2014).

It is believed that camel milk is a potential and functional health-promoting food supplement because of the presence of several bacteria and yeast that are reported to be beneficial for human health (Voss et al., 2005; Moon et al., 2007; Arsic et al., 2012; Paterson et al., 2014). People consumed fresh or transformed camel milk upon spontaneous fermentation into a traditional butter called shmen in Algeria (also used in diet by the Touareg communities in the Sahara; Abdelgadir et al., 1998). Camel milk is preferred more than the milk from other dairy animals and is reported to cure severe food allergies in children and in diabetic patients (Ehlayel et al., 2011; Shori, 2015; Zibaee et al., 2015). Furthermore, camel milk is suggested to exert several therapeutic activities (Hailu et al., 2016; Mihic et al., 2016). Numerous studies have also suggested that camel milk has distinct therapeutic benefits, such as antidiabetic (Korish, 2014; Korish et al., 2015; Mirmiran et al., 2017), anti-toxic (Al-Asmari et al., 2017; Khan, 2017), anti-viral (el Agamy et al., 1992; Lee et al., 2016; El-Fakharany et al., 2017), antibacterial (Rahimi and Kheirabadi, 2012; Cardoso et al., 2013; Soliman et al., 2015), anti-rheumatoid arthritis (Arab et al., 2017), anticancer (Korashy et al., 2012; Chen et al., 2014; Ayyash et al., 2018), and also wound healing (Ebaid et al., 2017) properties. However, the most dangerous or alarming situation is if people consume pasteurized camel milk that is contaminated with pathogenic bacteria. Therefore, heat treatments must be performed at high enough temperatures to kill all kinds of pathogens and other contaminating bacteria that are found to be present in the milk. It is known that the logarithmic decrease in microbe number is directly proportional to the source of microbial contamination, such as milking cattle, handlers, animals, trays, and transport conditions. Therefore, these parameters must be thoroughly sanitized so that the microbe number decreases sufficiently either by killing or inactivating. Pasteurization is the process of treatment of milk at a high temperature, such as at $63^{\circ} \mathrm{C}$ for 30 min using a low-temperature, long-time process, or at $72^{\circ} \mathrm{C}$ for $15 \mathrm{~s}$ using a HTST 
process, followed by a sudden cooling step at $4^{\circ} \mathrm{C}$ or to the ambient temperature, to ensure the destruction of any harmful contaminating bacteria (FDA, 2011). In a study conducted by Yehia et al. (2019), they identified an enterotoxigenic strain of Staphylococcus aureus, which was found to be able to survive in pasteurized camel milk even after heat treatment at $65^{\circ} \mathrm{C}(30 \mathrm{~min})$, $72^{\circ} \mathrm{C}(15 \mathrm{~min}), 80^{\circ} \mathrm{C}(10 \mathrm{~min}), 85^{\circ} \mathrm{C}(5 \mathrm{~min})$, and $90^{\circ} \mathrm{C}$ (2 min). The purpose of using pasteurization is to increase the safety of the milk that is being used by the consumer by destroying foodborne bacteria that might be present in the milk. Therefore, the detection of MRSA in pasteurized camel milk raises concerns of potential downstream infections because MRSA strains are resistant to heat treatments, further making the distribution of camel milk a possible high-risk concern for public health. Moreover, HTST processes, such as $88.3^{\circ} \mathrm{C}$ for $1 \mathrm{~s}, 90^{\circ} \mathrm{C}$ for $0.5 \mathrm{~s}, 93.8^{\circ} \mathrm{C}$ for $0.1 \mathrm{~s}, 96.2^{\circ} \mathrm{C}$ for $0.05 \mathrm{~s}$, or $100^{\circ} \mathrm{C}$ for 0.01 , can be used for the heat treatment of such milk (FDA, 2011).

The usual method that is practiced regularly to reduce the number of microorganisms, especially foodborne or pathogenic bacteria, is thermal treatment. If performed or applied suitably, thermal treatment can be an effective way to improve the quality of milk and other dairy products. Determination of the thermal death time (TDT) for methicillin- and heat-resistant S. aureus (MHRSA) is necessary to design a suitable and effective thermal procedure to destroy these organisms in camel milk. Buffo and Holley (2006) defined the TDT as the time required to kill a given number of microorganisms at a specific temperature.

Animal husbandry uses several antimicrobial agents to improve the growth of the animals and this has increased the selective pressure on the resistant bacterial strains in farm animals and animal products. The detection and isolation of Staphylococcus spp. from poultry-processing farms, chicken carcasses, milk, and dairy products provide substantial evidence that suggests that resistant microorganisms or their antibiotic resistance genes can be transferred from food, animals, or the environment to humans.

However, very limited information is available regarding the prevalence of MRSA in camel milk, especially for strains that exhibit both antibiotic resistance and heat resistance. Thus, the major aims of this study were (1) to isolate and identify the MHRSA from pasteurized camel milk samples that were collected from Al-Riyadh market in Saudi Arabia and differentiate them by using different tests such as catalase, staphylase coagulase, blood hemolysis, and PCR with mecA-specific primers, (2) to determine the antibiotic resistance by performing a susceptibility test, and (3) to determine the TDT (D- value) for MRSA at specific temperatures higher than the temperature used during usual pasteurization and compare with the D-value for the reference MHRSA strain to provide an explanation for its presence in pasteurized camel milk.

\section{MATERIALS AND METHODS}

\section{Sample Collection}

A total of 100 samples of pasteurized camel milk were collected from different retail markets in Al-Riyadh, Saudi Arabia, between March and May 2017. All of the samples were transported directly to the Laboratory of Food Microbiology, College of Food and Agriculture Sciences, King Saud University, and were refrigerated at $4^{\circ} \mathrm{C}$ until further use. To isolate the MRSA strains, 5 runs of 10 samples each (in duplicate) were performed and these experiments were executed over a period of 3 mo. The $S$. aureus strain ATCC 29737 was used as the reference strain. Staphylococcus aureus isolates were isolated from the pasteurized camel milk by using the streaking method in accordance with the EN ISO 6888-1 standard procedure of the International Organization for Standardization (International Standard Office, 2003). The milk samples were streaked on the Baird-Parker agar medium (CM1127, Oxoid, Waltham, MA) that was supplemented with egg yolk tellurite emulsion (SR0054, Oxoid). The agar plates were then incubated at $37^{\circ} \mathrm{C}$ for 48 to $72 \mathrm{~h}$ to allow the bacterial colonies to appear.

\section{Detection and Identification of S. aureus Strains in Camel Milk Samples}

Biochemical Identification: API Staph-Ident Strip System. The S. aureus isolates were identified biochemically using the API Staph system (BioMérieux, Marcy l'Etoile, France) according to the manufacturer's instructions.

PCR Identification: 16S RNA and Sa442 Gene Detection. Total genomic DNA was isolated from the S. aureus strain 29737 and the MHRSA isolates using the AxyPrep Bacterial Genomic DNA miniprep Kit (cat. no. AP-MN-BT-GDNA 50, Axygen Scientific Inc., Union City, CA) according to the manufacturer's instructions. Gene-specific primers were designed for the 16S rRNA gene (16S-forward: GAAAGCGTGGGGATCAAACA, 16S-reverse: TTGCGGGACTTAACCCAACA) and the Sa442 DNA fragment (Sa442-forward GTCGGGTACACGATATTCTTCACG, Sa442-reverse CTCTCGTATGACCAGCTTCGGTAC) using the available sequences of $S$. aureus strains and the MRSA 
isolates. The PCR was carried out using $10 \mu \mathrm{L}$ of $5 \times$ FIREPol Master Mix Ready to Load (12.5 $\mathrm{mM} \mathrm{MgCl}$; Solis BioDyne, Tartu, Estonia), $2 \mu \mathrm{L}$ of primer mix, 5 $\mu \mathrm{L}$ of DNA template, and $33 \mu \mathrm{L}$ of ultrapure water. The DNA amplification was performed in a Multigene thermal cycler (Labnet International Inc., Edison, NJ) using the following reaction conditions: $95^{\circ} \mathrm{C}$ for $5 \mathrm{~min}$; followed by 30 sequential cycles of $94^{\circ} \mathrm{C}$ for $1 \mathrm{~min}, 52^{\circ} \mathrm{C}$ for $1 \mathrm{~min}, 72^{\circ} \mathrm{C}$ for $1 \mathrm{~min}$; and a final elongation step at $72^{\circ} \mathrm{C}$ for $10 \mathrm{~min}$. A final extension step at $72^{\circ} \mathrm{C}$ for 5 min was performed after the completion of all the cycles. Aliquots of the PCR products were mixed with the 1-kb DNA ladder (GC-015-003, Genecraft, Münster, Germany), and were loaded into a $1.5 \%$ agarose gel (Sigma-Aldrich cat. no. 9539) containing ethidium bromide $(0.5 \mathrm{mg} / \mathrm{mL}$, cat no. 12182, ROTH, Karlsruhe, Germany). The agarose gel electrophoresis was performed using 10 $\times$ TBE buffer (Tris-Borate-EDTA, cat no. A0026, BIO Basic Inc., Montreal, Canada) for 30 min at $100 \mathrm{~V}$ (Electrophoresis Power Supply Model Consort EV243, Consort, Turnhout, Belgium). The amplified DNA fragments were visualized using the visual image analyzer software (Syngene, Frederick, MD).

\section{Identification of MRSA: PCR Detection of mecA Gene and Cefoxitin Resistance Gene}

Gene-specific primers for the methicillin-resistant gene including mecA forward (ACGTTCAATTTAATTTTGTT), and mecA reverse (GCGATTGTATTGCTATTATC) primers were designed for the detection of $m e c A$ gene. To identify the $m e c A$ gene of $S$. aureus and their integration, sequencing was performed using the PCR products and analyzed by direct DNA sequencing. Briefly, the PCR products were purified using the Axygen AxyPrep PCR Clean-Up Kit (Corning, Corning, $\mathrm{NY}$ ), according to the manufacturer's instructions. As previously described by Al-Shabanah et al. (2013), the purified PCR products were labeled with a fluorescent dye using the BigDye Terminator v3.1 Cycle Sequencing Kit (Applied Biosystems, Waltham, MA). Labeled oligonucleotides were then purified using the BigDye X Terminator Purification Kit (Applied Biosystems). The purified samples were sequenced using the automatic ABI 3500 genetic analyzer (Applied Biosystems). Chromatograms with sharp peaks, quality values $\geq 20$, and little or no background noise were considered to belong to a single enterotoxin $\mathrm{C}$ gene sequence. The obtained nucleotide sequences were further compared with the GenBank database using the Basic Local Alignment Search Tool (BLAST), which was developed by the National Cancer Institute (http://blast.ncbi.nlm.nih .gov/Blast.cgi). The effect of 30- $\mu$ g cefoxitin discs on $S$. aureus strain ATCC 29737 and the MRSA isolates was tested and the zone of inhibition was determined for each isolate (in diameter, $\mathrm{mm}$ ).

\section{Characterization of MRSA}

Antibiotic Resistance Profile. A comparison of antimicrobial susceptibility test between the $S$. aureus strain ATCC 29737 and the MHRSA isolates was performed. The tested bacterial isolates were obtained from overnight cultures that were inoculated from single colonies into the brain heart infusion broth (BHI, Oxoid code: CM1135). They were then applied to the surface of Mueller-Hinton agar (Oxoid, CM405) and the individual plates were used for performing the agar disk diffusion experiment (CLSI, 2018). A total of 25 different kind of antibiotic discs (Oxoid) containing the following components were prepared and tested with all the bacterial isolates: cefoxitin $(30 \mu \mathrm{g}, \mathrm{CT} 0119 \mathrm{~B})$, streptomycin $(10 \mu \mathrm{g}, \mathrm{CT} 0047 \mathrm{~B})$, colistin $(10 \mu \mathrm{g}$, CT0017B; $25 \mu \mathrm{g}, \mathrm{CT} 0065 \mathrm{~B}, \mathrm{CT} 0017 \mathrm{~B}, \mathrm{CT} 0065 \mathrm{~B})$, polymyxin B (300 U, CT0044B), cefadroxil (30 $\mu \mathrm{g}$, CT0453B), sulfamethoxazole $(25 \mu \mathrm{g}, \mathrm{CT} 0051 \mathrm{~B})$, nalidixic acid (30 $\mu \mathrm{g}$, CT0031B), amikacin (30 $\mu \mathrm{g}$, CT0107B), bacitracin (10 $\mu \mathrm{g}, \mathrm{CT0005B})$, kanamycin (30 $\mu \mathrm{g}$, CT0025B), cephalothin $(30 \mu \mathrm{g}$, CT0010B), tetracycline $(30 \mu \mathrm{g}, \mathrm{CT} 0054 \mathrm{~B})$, chloramphenicol (30 $\mu \mathrm{g}, \mathrm{CT} 0013 \mathrm{~B})$, ciprofloxacin (5 $\mu \mathrm{g}, \mathrm{CT} 0425 \mathrm{~B})$, linezolid (30 $\mu \mathrm{g}, \mathrm{CT} 1650 \mathrm{~B})$, ticarcillin

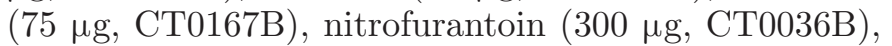
erythromycin $(15 \mu \mathrm{g}, \mathrm{CT} 0020 \mathrm{~B})$, vancomycin $(30 \mu \mathrm{g}$, CT0058B), ampicillin (10 $\mu \mathrm{g}$, CT0003B), amoxicillin/ clavulanic acid (30 $\mu \mathrm{g}$, CT0538B), sulfamethoxazole trimethoprim (25 $\mu \mathrm{g}, \mathrm{CT} 0052 \mathrm{~B})$, piperacillin (75 $\mu \mathrm{g}$, CT0261B), and amoxicillin (25 $\mu \mathrm{g}, \mathrm{CT} 0061 \mathrm{~B})$. The diameter of the zone of inhibition $(\mathrm{mm})$ for each condition was determined using the criteria recommended for S. aureus (CLSI, 2018). Based on the diameter of the antibiotic inhibition zone, the tested isolates were classified as sensitive or resistant strains. Results were interpreted from the size of the inhibition zone. Further, the inhibition zones were either considered to be sensitive, intermediate, or resistant (CLSI, 2018).

Virulence Profile (Slime Production). The slime produced by $S$. aureus strain ATCC 29737 and the MHRSA isolates was assessed quantitatively, which was based on the amount of color developed on the Congo red agar medium. The agar medium was prepared by adding the following components to $1 \mathrm{~L}$ of distilled water: tryptose soybean (30 g), sucrose (36 g), agar powder (20 g), and Congo red (0.8 g). Staphylococcus aureus strain ATCC 29737, S. epidermidis strain ATCC 12228 , and the MHRSA isolates were streaked on the Congo red agar medium, and incubated for $24 \mathrm{~h}$ at 37 ${ }^{\circ} \mathrm{C}$ under aerobic conditions. The color produced by the isolates was compared with the $S$. aureus strain ATCC 
29737, which is a slime-producing strain and was considered as a positive control, and S. epidermidis strain ATCC 12228, which is a nonproducer of slime and was considered as a negative control. Slime production results were interpreted as follows: strains producing intensive black, black, or reddish black colonies with a rough, dry, or crystalline consistency were considered to be normal slime producers, whereas those producing smooth red or Bordeaux red colonies were classified as nonproducers of slime, as reported previously (Kouidhi et al., 2010).

Biochemical Profiling (Staphylase, Coagulase, API Staph Profile). Biochemical characterization of the 10 presumptive MHRSA strains was performed by testing for the production of catalase, staphylase, and coagulase using rabbit plasma (bioMerieuxe, Lyophilized Rabbit Plasma, Ref. 55182), and blood hemolysis.

\section{Total Protein Profile}

Extraction of Genomic DNA. Overnight cultures of S. aureus strain ATCC 29737 and the MHRSA isolates were allowed to grow in BHI broth for $24 \mathrm{~h}$ at $37^{\circ} \mathrm{C}$, and then 1 to $2 \mathrm{~mL}$ of cells [optical density (OD) at $600 \mathrm{~nm}, 0.8-1.0$ ] were harvested by centrifuging at $22,673 \times g$ for $1 \mathrm{~min}$. The supernatant was discarded and the pelleted cells were completely resuspended by vortexing or tapping. Genomic DNA was extracted from S. aureus strain ATCC 29737 and MHRSA isolates using the G-spin Genomic DNA Extraction Kit (cat. no. 17121, iNtRON Biotechnology, SangdaewonDong, Joongwon-Ku, Sungnam, Kyungki-Do, Korea), according to the manufacturer's instructions.

Cell Extract Preparation. According to the method described by Yehia and Al-Dagal (2014), cell extracts were prepared with some modifications. Briefly, $100 \mu \mathrm{L}$ of the overnight cultures (S. aureus strain ATCC 29737 and presumptive isolates of MHRSA) were inoculated in $10 \mathrm{~mL}$ of BHI medium (Oxoid, CM1135) and were allowed to grow to an $\mathrm{OD}_{620}$ of 0.6 to 0.8 (3 to $4 \mathrm{~h}$ ). The cells were harvested and weighed, and then around $250 \mathrm{mg}$ of cells were resuspended in $100 \mu \mathrm{L}$ of TES buffer ( $50 \mathrm{~m} M$ Tris-HCl, pH 8, $1 \mathrm{~m} M$ EDTA, and $25 \%$ sucrose). Thereafter, $20 \mu \mathrm{L}$ of lysozyme $(50 \mathrm{mg} / \mathrm{mL})$ was added to the resuspended cells in the TES buffer and incubated at $37^{\circ} \mathrm{C}$ for $30 \mathrm{~min}$. After the cell lysis step, 5 to $10 \mu \mathrm{L}$ of $20 \%$ SDS was added, and the contents were mixed until the solution became visibly clear. The contents were stored at $-20^{\circ} \mathrm{C}$ for 1 or $2 \mathrm{~d}$ until further use.

$P A G E$. The SDS-PAGE analysis was performed using the cell isolates and the samples were electrophoresed using the method described by Scarcelli et al. (2001). Electrophoresis was performed on a $12 \%$ polyacrylamide running gel with a $4 \%$ stacking gel. The buffer system included a running buffer with a final concentration of $0.025 M$ Tris, $0.19 M$ glycine, $\mathrm{pH} 8.3$, and $100 \mu \mathrm{L}$ of sucrose $(50 \mathrm{~m} M$ Tris- $\mathrm{HCl}, \mathrm{pH}$ 8; $40 \mathrm{~m} M$ EDTA, pH 8; $0.75 M$ sucrose). Around 50 $\mu \mathrm{L}$ of cell extracts (of reference and bacterial isolates) were analyzed. Electrophoresis was performed at $25^{\circ} \mathrm{C}$ in a vertical tank apparatus using a constant-voltage power supply, until the bromophenol blue tracking dye reached the bottom of the gel. Gels were stained with $0.25 \%$ Coomassie Brilliant Blue R-250 (Bio-Rad, Marnesla Coquette, France), which was prepared in a solution of water, methanol, and acetic acid at a ratio of 6.5:2.5:1, respectively, for $18 \mathrm{~h}$ at room temperature. The gels were then destained by continuous agitation in the methanol, acetic acid, and water solvent (20:10:70 $\mathrm{vol} / \mathrm{vol} / \mathrm{vol}$, respectively) until the protein bands were clearly visible. Total cell protein profiles of presumptive MHRSA isolates were compared with $S$. aureus strain ATCC 29737 under denaturing conditions using SDS.

Determination of $D$-Value. According to the protocol described by Yehia et al. (2019), the solutions containing the MRSA isolates and S. aureus strain ATCC 29737 (control) were prepared for thermal destruction or inactivation trials. Active cultures were obtained by inoculating single colonies of the $S$. aureus strains into the $\mathrm{BHI}$ broth and were allowed to grow at $37^{\circ} \mathrm{C}$ for 24 h. Around $1 \mathrm{~mL}$ of each of the $24 \mathrm{~h}$ active cultures were diluted into the screw test tubes containing $9 \mathrm{~mL}$ of BHI medium. At the $0 \mathrm{~s}$ time point, the number of cells in the inoculated medium ranged between $10^{6}$ to $10^{7}$ per $\mathrm{mL}$. Because the active culture of $S$. aureus tends to form clusters, the cells were dispersed by vortexing at the maximum speed for 1 min before the dilution in the BHI medium. Duplicate tubes containing the diluted solutions were prepared and were exposed to heat in a water bath at $90^{\circ} \mathrm{C}$ for $0,10,20,30,40,50$, and 60 s. After each heat treatment, the tubes were quickly chilled in an ice water bath for $20 \mathrm{~s}$. For counting the number of surviving bacteria, the solutions from each tube were serially diluted to $10^{2}$ and $10^{3}$ fold in duplicate. After dilution, $1 \mathrm{~mL}$ of solution from each tube was spread on the BHI agar plates (code: CM1136) that were prepared after sterilizing at $121^{\circ} \mathrm{C}$ for $15 \mathrm{~min}$, and cooling to $50^{\circ} \mathrm{C}$. The dishes were incubated at $37^{\circ} \mathrm{C}$ for 24 to $48 \mathrm{~h}$. Thereafter, the colony-forming units per milliliter of the surviving cells were recorded for each treatment. The optical densities of the cultures in the dilution tubes were also recorded after incubating at $37^{\circ} \mathrm{C}$ for $24 \mathrm{~h}$. The D-values were determined by generating the survivor plots and by performing the linear regression analysis. The $\mathrm{D}$-values are reported in seconds, and are defined as the time required for achieving a 1-log reduction in the count of bacterial 
population at the designated temperature (Holdsworth, 1997).

\section{RESULTS AND DISCUSSION}

\section{API Staph-Ident Strip System}

As shown in Table 1, results from the API StaphIdent system test revealed that all the 10 MHRSA isolates that were given a 7 -digit identification number were identified as $S$. aureus strain, with the percentage identity between 90 and $97.4 \%$, according to the identification software (bioMérieux).

\section{PCR Identification: 16S RNA and Sa442 Gene Detection}

As shown in Table 2, all isolates contain both $16 \mathrm{~S}$ rRNA and Sa442 DNA fragments, but only the $S$. aureus MHRSA stains additionally contain the mecA gene. Few reports on $S$. aureus isolates have been found to be negative for the Sa442 fragment; therefore, use of a single gene or the DNA fragment specific for the 442 bp undefined chromosomal fragment has recently been the method of choice for the identification of $S$. aureus using multiplex PCR. The Sa442 DNA fragment (an undefined 442 bp sequence), a popular DNA target for the identification of $S$. aureus by the PCR method, was originally described by Martineau et al. (1998).

\section{Identification of MRSA: PCR Detection of mecA Gene and Cefoxitin Resistance Test}

Identification of mecA Gene in the S. aureus Isolates. Direct DNA sequencing of the S. aureus mecA PCR amplicon using the mecA $\mathrm{F}$ primer as the forward sequencing primer was performed to sequence the unique hypervariable region of the $S$. aureus strain, as shown in Figure 1. The submission of this 300-bp sequence to GenBank for BLAST alignment analysis generated a return report. The sequence was found to be located in the chromosomal region of penicillin binding protein 2a (mecA) gene of $S$. aureus strain CS100, matching with partial CDS (coding sequence), and sequence ID KX689749.1. Ali and Mahmoud (2017) isolated 5 different isolates of MRSA from raw camel milk distributed in Al-shalateen area, Egypt, which were found to contain the mecA gene. Twentysix isolates were found to be methicillin-susceptible $S$. aureus strains. The whole genome sequence of $S$. aureus was annotated and visualized by rapid annotation using subsystem technology (http://www.theseed .org/RASTPaperSupplementalMaterial/), which is a fully automated tool for annotating complete or nearly complete bacterial genomes.

As mecA gene amplification was used for rapid identification of MRSA strains, Sa442 DNA fragment has recently been identified as a popular DNA target for the identification of $S$. aureus strains.

Cefoxitin Resistance Test. The effect of $30-\mu \mathrm{g}$ cefoxitin discs on S. aureus strain ATCC 29737 and the MHRSA isolates was assessed. Staphylococcus aureus strain ATCC 29737 was found to be sensitive to cefoxitin $(30 \mu \mathrm{g})$ and the zone of inhibition was estimated as $25 \mathrm{~mm}$ in diameter, while the MHRSA isolates were resistant and not affected by cefoxitin. The reason for using cefoxitin to detect methicillin-resistant strains of $S$. aureus was mainly because methicillin is no longer commercially available in the United States. Many researchers have also used oxacillin in place of methicillin, but it has been found that cefoxitin is a better inducer of mecA, and tests using cefoxitin have given more reproducible and accurate results than tests with oxacillin. Cefoxitin is a strong inducer of mecA, which appears to be less affected than oxacillin by penicillinase-hyperproducing isolates. Cefoxitin is also more reliable as it can detect oxacillin-sensitive/cefoxitin-resistant mecC MRSA, which also has an epidemiological impact on the reported diseases in humans and animals (Paterson et al., 2014), and is currently recommended in the Clinical and Laboratory Standards Institute guidelines (Swenson and Tenover, 2005; Swenson et al., 2007). According to the disk diffusion criteria of the National Committee for Clinical Laboratory Standards (CLSI, 2018), cefoxitin resistance is defined as zone diameters $\leq 19 \mathrm{~mm}$ for resistance, and $\geq 20 \mathrm{~mm}$ for susceptibility. In a study conducted by Skov et al. (2003), they tested 30- $\mu$ g cefoxitin discs on Oxoid Iso-Sensitest agar and reported a zone diameter of $<29 \mathrm{~mm}$ as an appropriate diameter for identification of methicillinresistant strains, and explained it as most accurate for the detection of methicillin-resistant strains using either disk diffusion or agar dilution methods. These tests clearly differentiate between MRSA strains from methicillin-susceptible $S$. aureus strains. Detection of $m e c A$, or PBP2a, and its product, is always considered as the gold standard for identifying MRSA species. However, molecular biology methods are not available in all laboratories, and therefore, phenotypic methods such as disk diffusion using cefoxitin, oxacillin, or both, are not suitable for determining methicillin resistance in $S$. aureus strains particularly in strains with heterogeneous methicillin resistance that require induction of PBP2a by specific antibiotics for their detection (Brown et al., 2005). Cefoxitin has been recommended as the best agent to be used for the detection of MRSA 


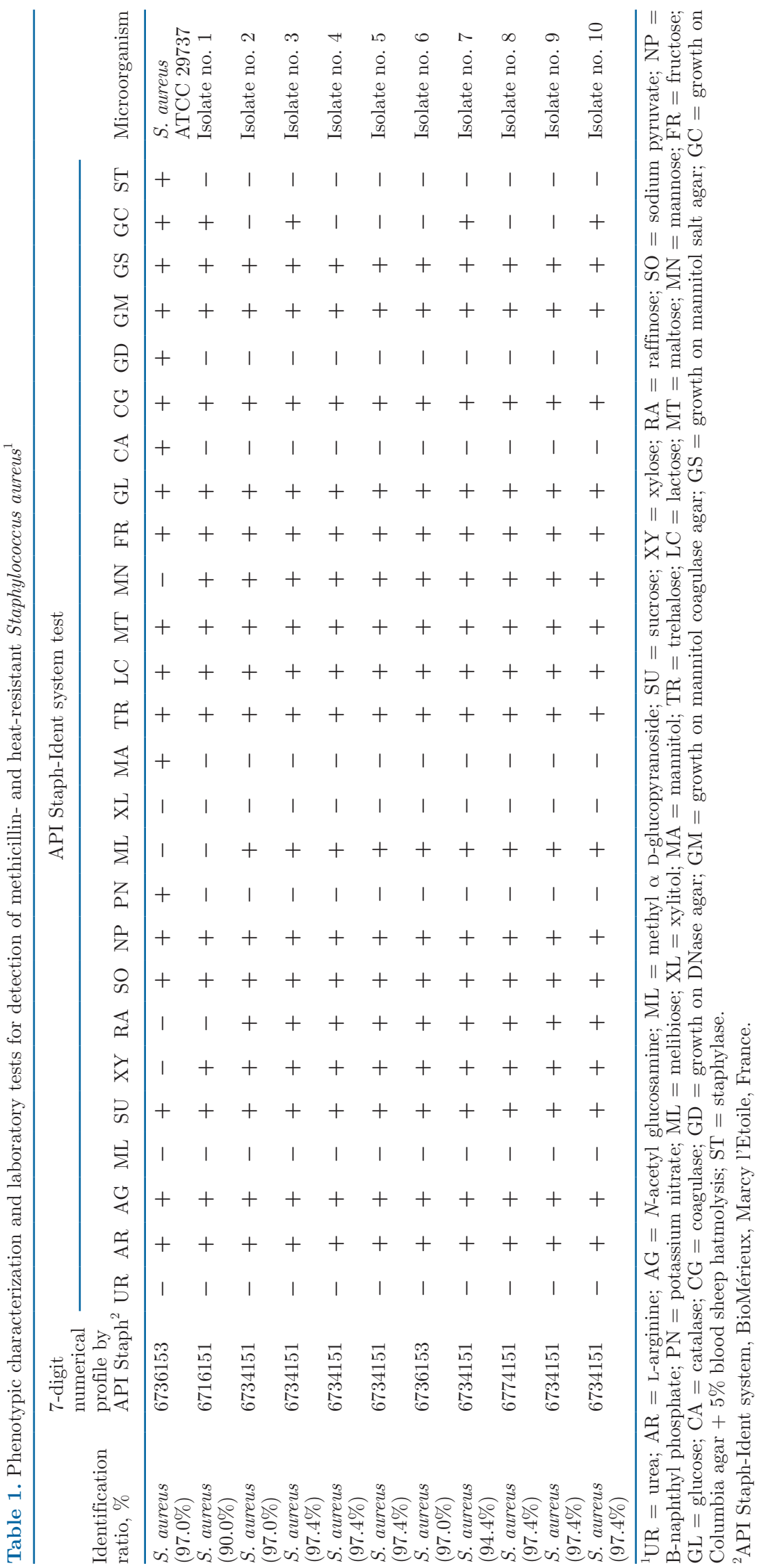


Table 2. PCR of $16 \mathrm{~S}$ rRNA, mecA, and Sa442 genes in Staphylococcus aureus strain ATCC 29737 and methicillin- and heat-resistant $S$. aureus (MHRSA)

\begin{tabular}{|c|c|c|c|c|c|c|c|}
\hline \multirow[b]{2}{*}{ Organism } & \multicolumn{2}{|c|}{$16 \mathrm{~S}$ rRNA } & \multicolumn{2}{|c|}{ mecA } & \multicolumn{2}{|c|}{$\mathrm{Sa} 442$} & \multirow[b]{2}{*}{ No. of isolates } \\
\hline & $\mathrm{PCR}^{+}$ & $\mathrm{PCR}^{-}$ & $\mathrm{PCR}^{+}$ & $\mathrm{PCR}^{-}$ & $\mathrm{PCR}^{+}$ & $\mathrm{PCR}^{-}$ & \\
\hline S. aureus ATCC 29737 & 1 & - & - & - & 1 & - & 1 \\
\hline S. aureus (MHRSA) & 10 & 0 & 10 & 0 & 10 & 0 & 10 \\
\hline
\end{tabular}

strains using phenotypic methods. Although oxacillin fails to detect MRSA strains, it is expected that cefoxitin can be the best agent because cefoxitin is a strong inducer of PBP2a expression and does not appear to be affected by hyperproduction of penicillinase, which may demonstrate methicillin resistance (Felten et al., 2002; Brown et al., 2005). Furthermore, cefoxitin has a high affinity for staphylococcal penicillin binding protein 4, which along with PBP2a overproduction might also contribute to methicillin resistance (Felten et al., 2002).

\section{Characterization of MRSA}

Antibiotic Resistance Profile. All the strains of methicillin-resistant Staphylococcus aureus showed resistance against all classes of antibiotics, such as $\beta$-lactam, polymyxin E, aminoglycosides, cyclic peptides, sulfonamide, quinolone, fluoroquinolone, and oxazolidone. These 10 MRSA strains showed intermediate resistance against macrobid, chloramphenicol, and glycopeptide. They also exhibited resistance to the 15 of the 25 antibiotics tested (60\%), compared with the S. aureus strain ATCC 29737, which was resistant to only $20 \%$ of the tested antibiotics (as shown in Table 3). Also, 8 antibiotics had no effect on any of the MRSA isolates or S. aureus strain ATCC 29737. These included streptomycin $(10 \mu \mathrm{g}, \mathrm{CT} 0047 \mathrm{~B})$, colistin $(25$ $\mu \mathrm{g})$, polymyxin B (300 U), amikacin $(25 \mu \mathrm{g}, \mathrm{CT} 0107 \mathrm{~B})$,

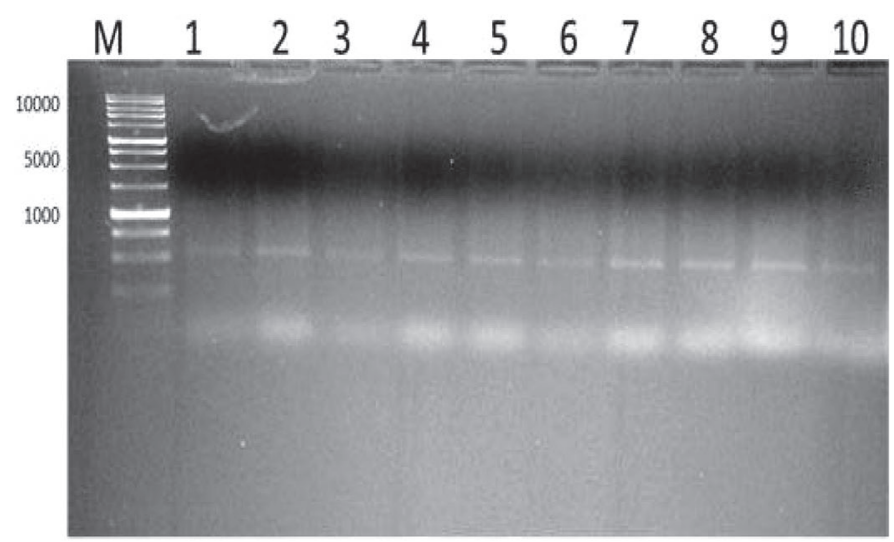

Figure 1. PCR amplification of mecA from the 10 selected Staphylococcus aureus isolates (lanes 1-10). M: DNA marker.

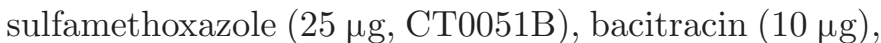
and kanamycin $(30 \mu \mathrm{g})$. Four antibiotics were highly effective against all the MRSA isolates and $S$. aureus strain ATCC 29737, which included amikacin $(30 \mu \mathrm{g})$, sulfamethoxazole trimethoprim $(25 \mu \mathrm{g})$, piperacillin $(75$ $\mu \mathrm{g})$, and amoxicillin $(25 \mu \mathrm{g})$. The antibiotics with intermediate activity were ticarcillin $(75 \mu \mathrm{g})$, nitrofurantoin $(300 \mu \mathrm{g})$, erythromycin $(15 \mu \mathrm{g})$, and ampicillin (10 $\mu \mathrm{g})$. Therefore, the MRSA isolates were able to grow under stress conditions and resist a broad spectrum of antibiotics, which might have resulted from feeding, or treating the animals with different antibiotics.

Antibiotic-resistant strains of MRSA can be divided into 2 categories, one carrying innate resistance and the other with acquired resistance. Natural or innate resistance refers to an inherent resistance to an antibiotic beyond its usual spectrum (Haddadin et al., 2002). On the other hand, acquired resistance to an antibiotic might be developed in previously sensitive microorganisms resulting in increased MIC to a particular antibiotic (Haddadin et al., 2002). High-grade acquired resistance appears when a single-step mutation develops during or after the antibiotic-treatment, resulting in increased MIC for a previously susceptible isolate to extremely high antibiotic levels even beyond therapeutic doses (Georgopapadakou et al., 1986). Bacterial cell wall synthesis is inhibited by $\beta$-lactams, which might act as suicide substrates for the transpeptidase domain of penicillin binding proteins (Zervosen et al., 2012). Methicillin resistance is in regard to the $\beta$-lactam compounds that are not hydrolyzed by $\beta$-lactamase, such as methicillin, cefoxitin, oxacillin, cloxacillin, dicloxacillin, and nafcillin. Methicillin-resistant isolates and methicillin-resistant coagulase negative Staphylococci isolates are broadly resistant to penicillin and cephalosporins. Methicillin resistance is mainly mediated by $m e c A$, which encodes for an additional penicillin binding protein, PBP2a, which has a low affinity for all the $\beta$-lactams (Weese et al., 2010). However, harboring $m e c A$ gene is not sufficient for methicillin resistance because some $S$. aureus isolates that contain the gene are still shown to be susceptible to methicillin (Hiramatsu, 1995; Niemeyer et al., 1996; Rubin et al., 1999).

In a study that evaluated the efficacy of fosfomycin used in combination with other drugs, it was found that 
Yehia et al.: STAPHYLOCOCCUS AUREUS CONTAMINATION IN CAMEL MILK

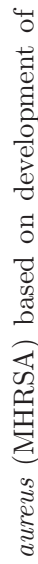

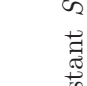$$
\frac{\pi}{\sqrt[\pi]{n}}
$$

(5)

$$
\text { 产 }
$$

$$
\text { 雚 }
$$

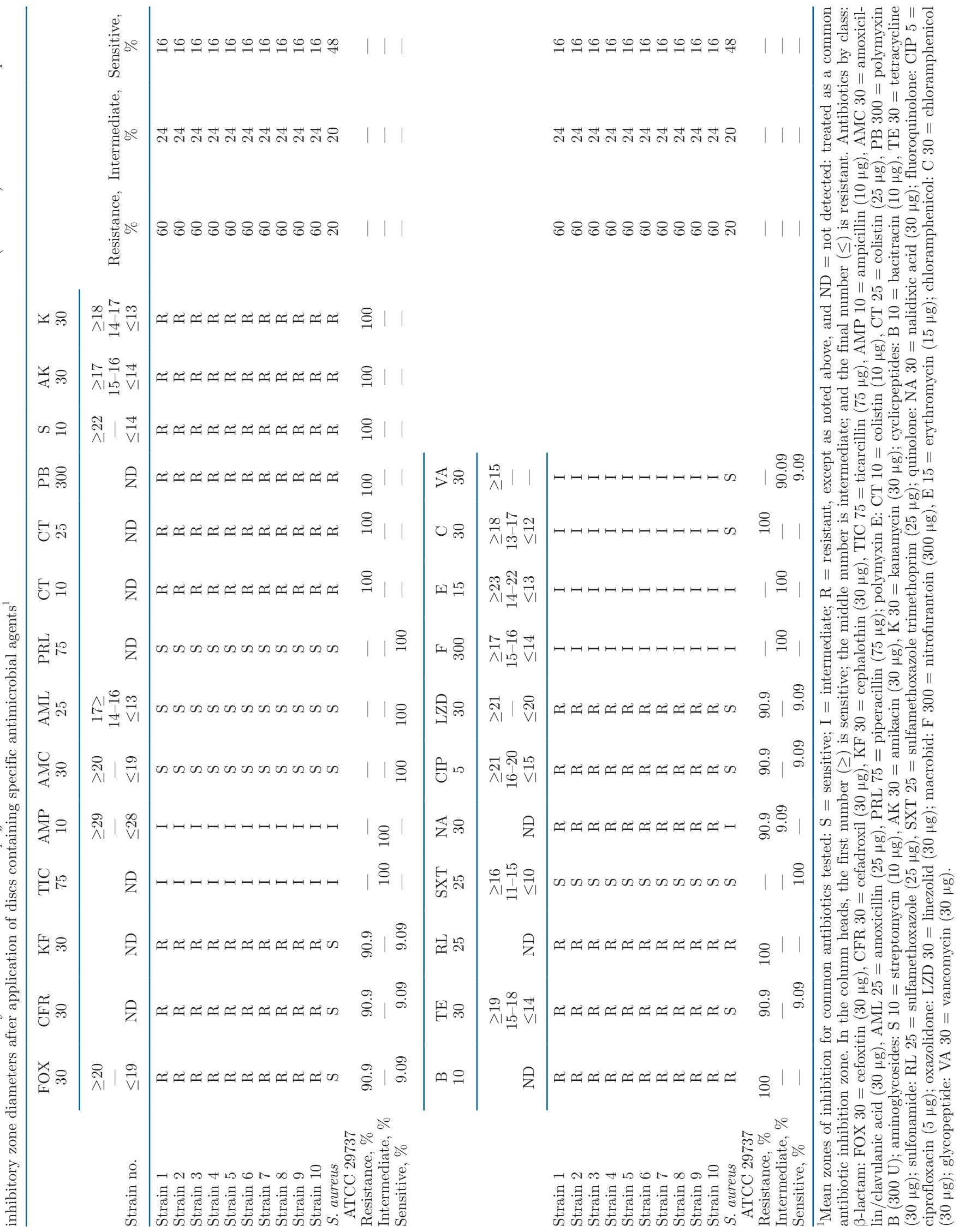

Journal of Dairy Science Vol. 103 No. 7, 2020 
fosfomycin is less effective against MRSA (Simonetti et al., 2018). In a burn unit at Tokyo Women's Medical University Hospital, 12 different antibiotics were tested against 32 strains of MRSA that were isolated from the wounds of burn patients. The tested antibiotics included minocycline, ofloxacin, sulbactam/cefoperazone, panipenem, ampicillin, fosfomycin, flomoxef sodium, imipenem, cefotiam, cefmetazole, arbekacin, and vancomycin, which were used either alone or in combination. It was found that both arbekacin and vancomycin were effective in suppressing the in vitro bacterial growth, but 10 other antimicrobial agents, when used alone, were ineffective. The combination of arbekacin or vancomycin with fosfomycin demonstrated high efficacy against all the tested MRSA strains (Nakazawa et al., 2003). The mortality rate of staphylococcal bacteremia infections decreased from $\sim 70 \%$ to $\sim 25 \%$ in 1944 (Rubin et al., 1999), due to the discovery of penicillin. However, 10 yr later the mortality rates again reached to $45 \%$ as the $S$. aureus became resistant to penicillin. Following the development of the group of isoxazolyl penicillins, including methicillin and flucloxacillin, and due to their clinical use, the mortality due to staphylococcal bacteremia again decreased to $25 \%$. The development of methicillin resistance was documented almost as soon as these drugs became available in the market (Jevons et al., 1963). Therefore, the mortality rate again began to increase due to the development of MRSA strains. Meta-analysis of 30 studies revealed that the average mortality rate was $36 \%$ due to bacteremia caused by MRSA in comparison to a $24 \%$ mortality rate due to septicemia caused by methicillin-susceptible S. aureus (Cosgrove et al., 2003). Seven studies in this meta-analysis report recorded mortality rates over $50 \%$ due to bacteremia caused by MRSA, with 2 of them being over 80\% (Kuikka and Valtonen, 1994; Cosgrove et al., 2003). Currently, the clinical consequences of resistance to vancomycin are further complicating the management of MRSA infections (Fridkin et al., 2003). A mortality rate of $63 \%$ was reported for patients who were infected with a vancomycin-intermediate $S$. aureus strain (Fridkin et al., 2003). However, the mortality rate was even higher $(78 \%)$ in patients with septicemia caused by a vancomycin-intermediate $S$. aureus strain.

Slime Production. Slime production was detected in S. aureus strain ATCC 29737, and to a similar extent in all the 10 MRSA isolates. The negative control, $S$. epidermidis strain did not produce any slime. Many virulence factors are known to increase the potential of disease development by $S$. aureus, which can be described as secreted toxins that interfere directly with the host metabolism (Otto, 2014). We agree with the previous findings (Christensen et al., 1982; Davenport et al., 1986; Kleeman et al., 1993; Ammendolia et al., 1999; Mack et al., 2000) that demonstrated the relationship between virulence and slime production. These authors reported that virulence is highly associated with the slime production by some strains of staphylococci. This has also been observed in CNS, in which a loosely bound exopolysaccharide layer (slime) capsule has been associated with sepsis and with intravenouscatheter-related bacteremia and other prosthetic device infections (Ishak et al., 1985; Diaz-Mitoma et al., 1987; Etienne et al., 1988; Rupp and Archer, 1994). Similarly, some strains of $S$. aureus were shown to possess bacterial capsules, which are closely associated with the bacterial cell wall. These strains were also shown to possess an extracapsular and labile extra polysaccharide structure (Caputy and Costerton, 1984). Slime production by $S$. aureus is thought to be a potential virulence factor. Previously, some authors have reported a higher colonization capacity in slime-producing $S$. aureus strains compared with strains that do not produce slime. Hence, slime production by $S$. aureus strains might play a role in the establishment of infection (Caputy and Costerton, 1984; Ammendolia et al., 1999). It has also been reported that slime-producing $S$. aureus strains might exhibit higher antibiotic resistance than the non-slime-producing counterparts (Kloos and Bannerman, 1994).

\section{Biochemical Profile (Staphylase, Coagulase, API-Staph Profile)}

Staphylase Test. The staphylase test denotes the agglutination performance and the detection of clumping factor, as indicated in the results (refer to Table 1). We could demonstrate that the $S$. aureus strain ATCC 29737 exhibited a positive result of red clumping. However, the staphylase agglutination test was negative for all the MRSA isolates, indicating that the MRSA isolates were phenotypically negative for the clumping factor. The staphylase test is a rapid and accurate method to identify the MRSA strains in the laboratory and hospitals, and also in food products, as the results are available within a few minutes. Staphylase kits are designed to detect the clumping factor or protein A (or both) of $S$. aureus strains, but they are not suitable to identify certain MRSA strains (Caputy and Costerton, 1982; Brakstad et al., 1993; Schwarzkopf, 1995). Davies (1997) reported the sensitivity of the staphylase test, which is in agreement with our results. Routine laboratory detection of $S$. aureus isolates is based on rapid agglutination tests. However, the inability of agglutination assays to identify MRSA has also been demonstrated (Weist et al., 2006). A study conducted 
by Hsueh et al. (1999) collected 25 MRSA isolates from December 1997 to March 1998, and all of them exhibited negative staphylase reactions.

Coagulase and Catalase Test. From our results, we found that all the 10 MRSA isolates and the $S$. aureus strain ATCC 29737 were positive for coagulase (refer to Table 1). The S. aureus strain ATCC 29737 was also positive for catalase, but the 10 MRSA isolates were negative for catalase. Testing for $\beta$-hemolysis on blood sheep agar resulted in clear zones around $S$. aureus strain ATCC 29737, and similar results were observed for several of the MRSA isolates including 1, 3,7 , and 10, whereas the other MRSA isolates 2, 4, $5,6,8$, and 9 were negative for $\beta$-hemolysis as tested on sheep blood agar. We also observed that mannitol was well fermented by $S$. aureus strain ATCC 29737 and the 10 MRSA isolates as tested on the mannitol coagulase agar. The $\mathrm{pH}$ of the medium surrounding the coagulase-positive colonies changed, and the Bromocresol purple indicator turned yellow, exhibiting yellow zones around the colonies. An opaque area composed of coagulated plasma was formed around the colonies of the coagulase-positive strains. Staphylococcus aureus strain ATCC 29737 and the MRSA isolates fermented the mannitol in mannitol salt agar, producing yellowcolored colonies surrounded by yellow zones. Staphylococcus aureus strain ATCC 29737 was also positive for DNase activity on DNase agar, which was visualized as clear zones around the colonies when the plates were flooded with $1 N$ hydrochloric acid, whereas the MRSA isolates were all negative for DNase activity. Di Salvo (1958) confirmed a correlation between coagulase activity and DNase activity by incorporating DNA along with calcium chloride into the medium to activate the enzyme.

Many commercially available kits for the identification of $S$. aureus are being used in different laboratories (Kloos and Bannerman, 1995). Although the rabbit coagulase plasma tube test remains the gold standard for the identification of $S$. aureus, the time required to perform this test is between 4 and $24 \mathrm{~h}$ to ensure that precise results are obtained. On the other hand, the slide coagulase test, including the latex agglutination and hemagglutination method for the detection of the presence of clumping factor or protein A, is more rapid and an attractive alternative (Cremer and Gruneberg, 1988; Fournier et al., 1993). However, the major drawback of some of the commercial kits is their inability to accurately detect MRSA, with false-negative rates being as high as 25\% (Ruane et al., 1986; Piper et al., 1988).

In the literature, no such method is described to conclusively differentiate between coagulase and clumping factor, which is the fibrinogen-binding determinant on the $S$. aureus cell surface. This lack of clarity seems to be due to the unsteady terminology; for instance, the clumping factor is sometimes referred to as bound coagulase. Although coagulase is considered as an extracellular protein, a small fraction is tightly bound to the bacterial cell surface, where it can react with prothrombin. It has recently been shown that extracellular coagulase can also bind to fibrinogen, as well as to thrombin. Genetic studies show unequivocally that coagulase and clumping factor are 2 distinct entities. Specific mutants lacking coagulase do retain clumping factor activity, and the clumping factor mutants express normal levels of coagulase (Baron, 1996).

\section{Total Protein Profile}

The total protein profiles of the presumptive MHRSA isolates were analyzed by using SDS-PAGE analysis. Proteins were loaded and allowed to run on the $12 \%$ polyacrylamide gel. Reproducible profiles were obtained after staining with Coomassie brilliant blue, as shown in Figure 2. The total cell protein profile of each isolate was similar in band constitution and intensity compared with the reference $S$. aureus strain ATCC 29737. However, due to the high degree of similarity observed among the samples, banding patterns reached a threshold of $100 \%$. Thus, we could conclude that SDS-PAGE was not efficient for distinguishing between the MHRSA isolates, and therefore all the isolates were closely related. These results were in agreement with the results of a previous study conducted by Stephenson et al. (1986).

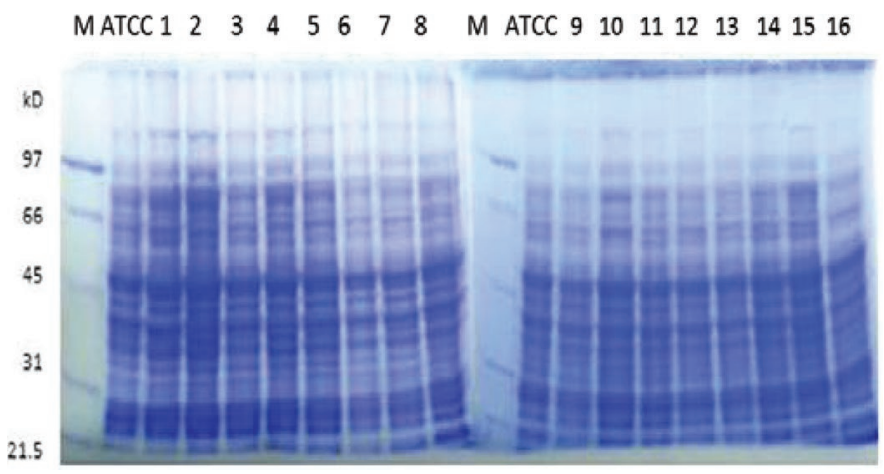

Figure 2. Total protein profiles of methicillin- and heat-resistant Staphylococcus aureus (MHRSA) isolates by SDS-PAGE. Lane M = molecular weight standard in $\mathrm{kDa}$; lane $\mathrm{ATCC}=S$. aureus total protein as a positive control; lanes 1-8 and $9-16=$ different MHRSA isolates. 
A Isolate No. 1

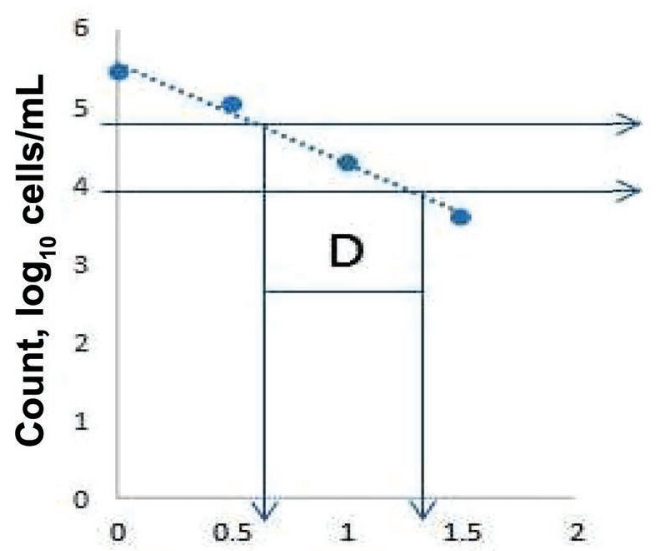

C Isolate No. 3

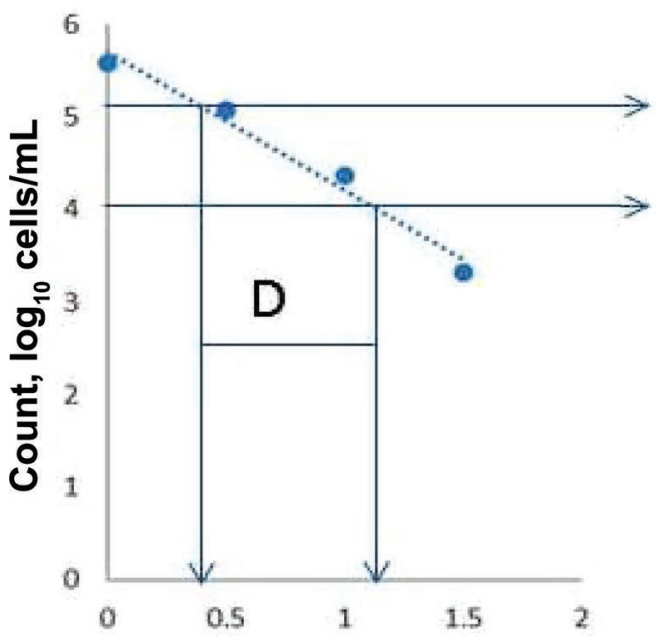

E Isolate No. 5

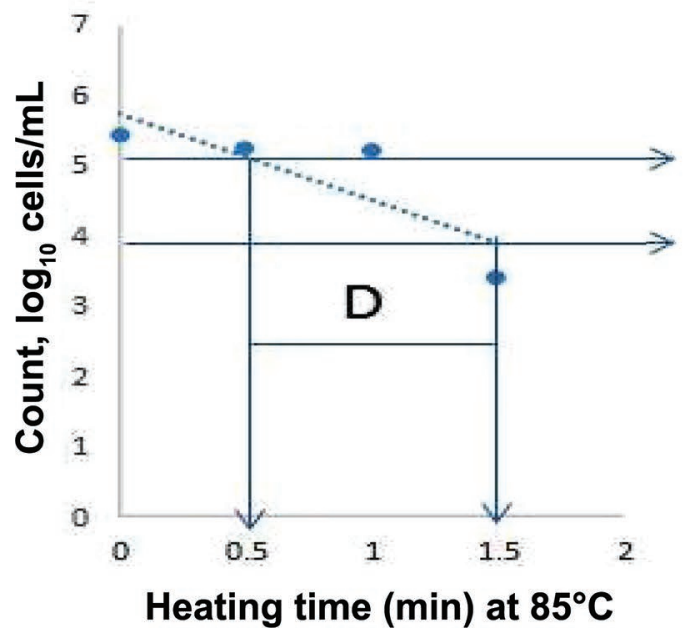

B Isolate No. 2

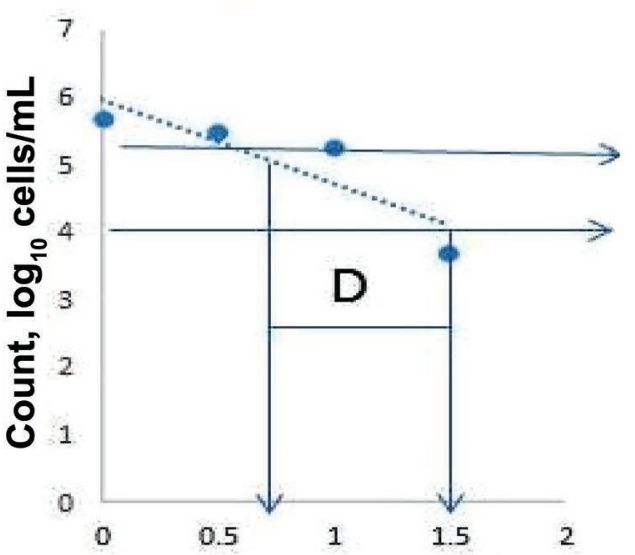

D Isolate No. 4

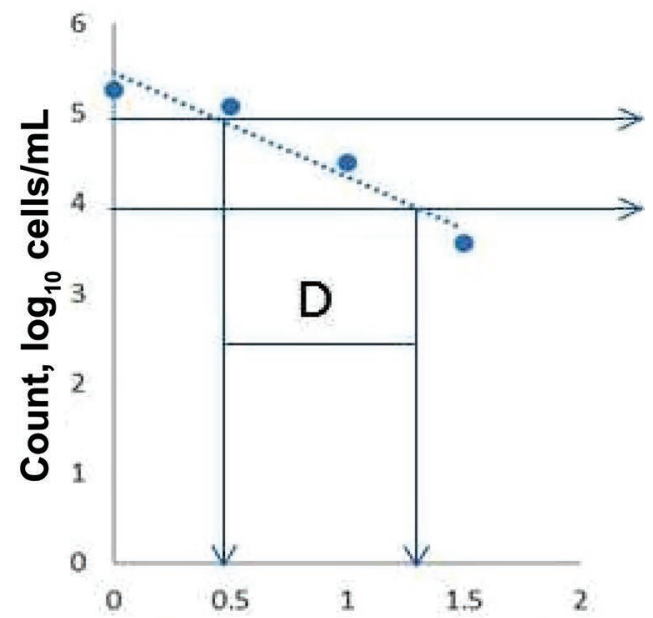

F Isolate No.6

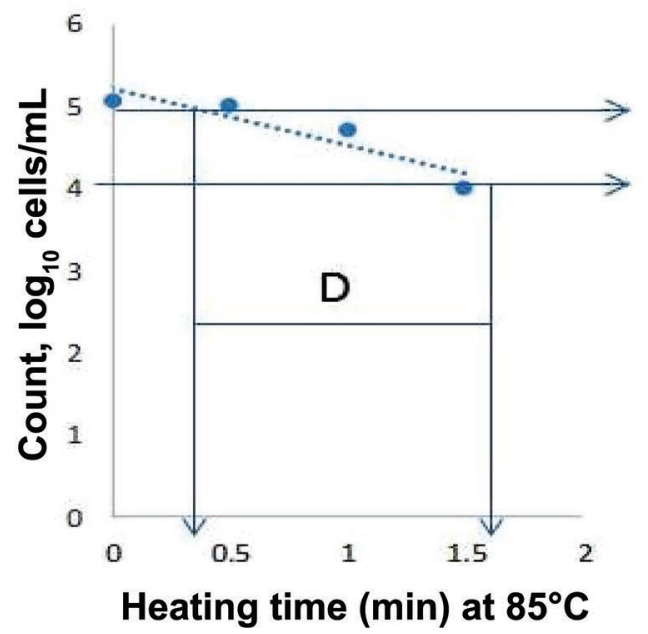

Figure 3. (A-J) Decimal reduction time (D-value) for the 10 isolates of Staphylococcus aureus mecA at $85^{\circ} \mathrm{C}$ for $0,0.5,1$, and 1.5 min. 


\section{D-Value Determination}

The D-value, which is also known as the decimal reduction time, is the time required to inactivate or reduce $90 \%$ of the initial population of the microorganism, for instance, from $10^{7}$ to $10^{6}$ at a given temperature. This time or value might vary considerably among different strains of microorganisms, but might also be similar between microorganisms of the same genus and species, which further depend on the treatment given to the microorganisms and the kind of food that is being contaminated. As shown in Figure 3, the D-values for the 10 isolates of MHRSA, when treated at $85^{\circ} \mathrm{C}$, were $108,120,120,126,138,150,120,108,120$, and $126 \mathrm{~s}$, respectively. Thus, the mean $\mathrm{D}_{85}$ value was estimated as 111 s. In Figure 4A, we have shown the results of heat treatment at $85^{\circ} \mathrm{C}$ for $60 \mathrm{~s}$, upon growing all the isolates in liquid medium. The data were collected as OD values for each condition after heat treatment and transformed into $\log _{10}$ scale for generating the standard curve. The reference strain, S. aureus ATCC 29737, and the isolates 3, 6, and 7 failed to grow after the heat treatment in BHI. In Figure 4A, we have illustrated the data collected as $\log _{10}$-transformed OD values. Also, isolates 1 and 2 exhibited a weak ability to grow, whereas isolates $4,5,8,9$, and 10 grew well in BHI. When the temperature of the treatment was elevated to $90^{\circ} \mathrm{C}$ for $60 \mathrm{~s}$ and $90 \mathrm{~s}$, we observed that the 3 isolates 4 , 9, and 10 did not grow in BHI, as shown in Figure 4B and $4 \mathrm{C}$, respectively. At the treatment of $95^{\circ} \mathrm{C}$ for 120
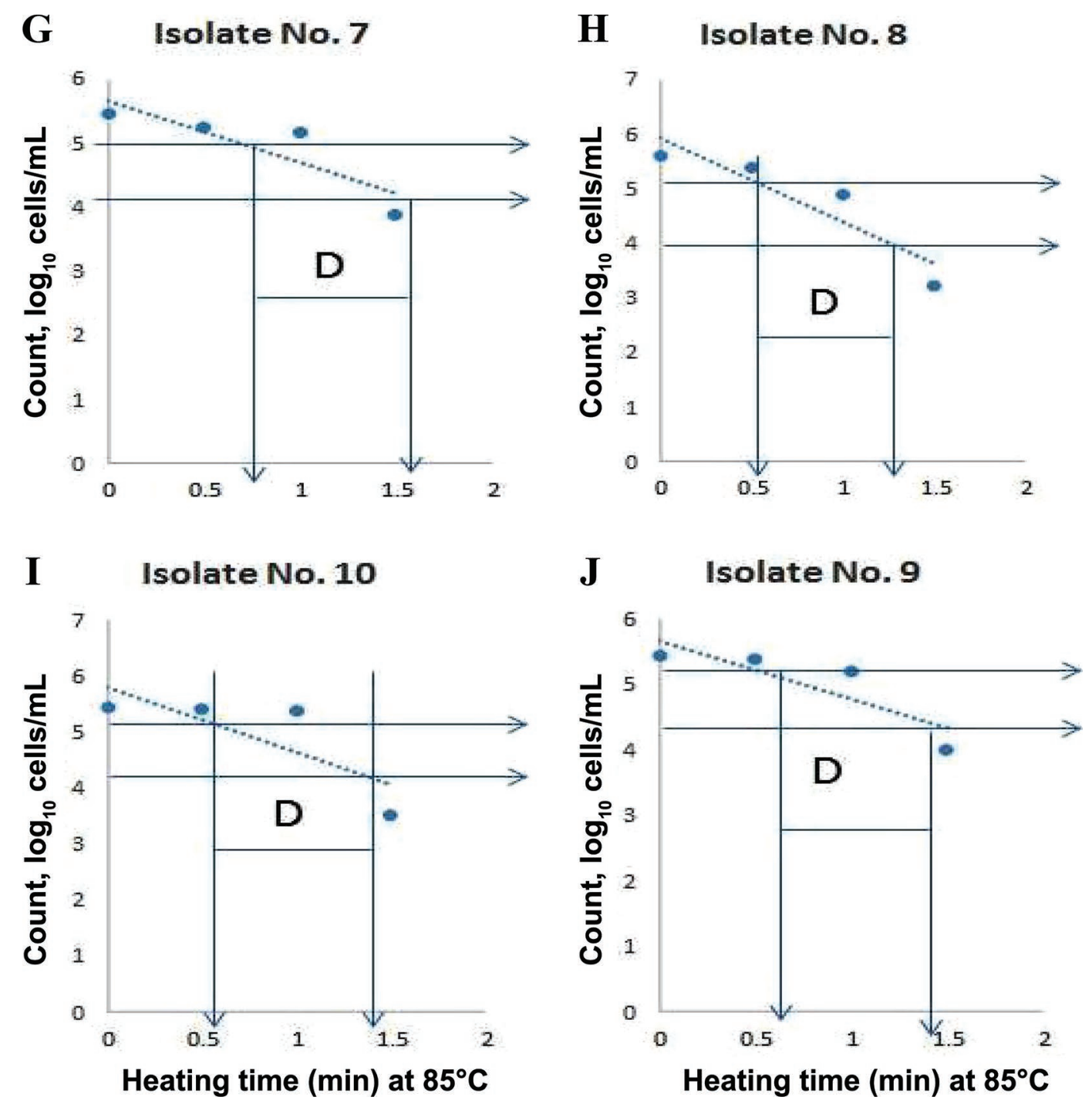

Figure 3 (Continued). (A-J) Decimal reduction time (D-value) for the 10 isolates of Staphylococcus aureus mecA at $85^{\circ} \mathrm{C}$ for $0,0.5,1$, and $1.5 \mathrm{~min}$. 
A
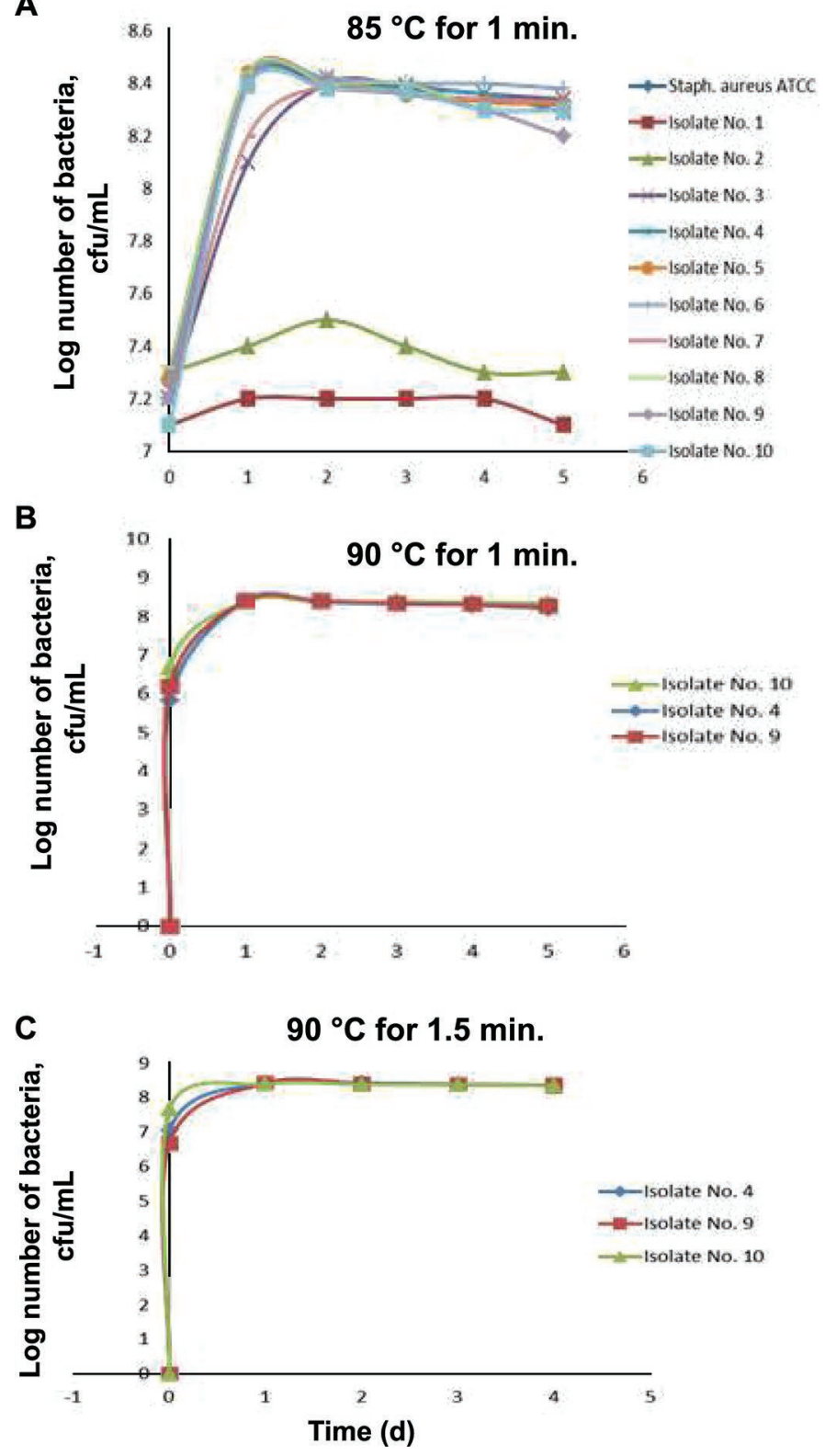

Figure 4. Effect of heat treatment on the cell viability count (cfu/ $\mathrm{mL}$ ) of Staphylococcus aureus strain ATCC 29737 and methicillin- and heat-resistant $S$. aureus (A) at $85^{\circ} \mathrm{C}$ for $1 \mathrm{~min},(\mathrm{~B})$ at $90^{\circ} \mathrm{C}$ for $1 \mathrm{~min}$, and $(\mathrm{C})$ at $90^{\circ} \mathrm{C}$ for $1.5 \mathrm{~min}$.

$\mathrm{s}$, none of the 10 isolates were found to grow in BHI. Thus, all the MRSA isolates that could grow at high temperatures ranging from 85 to $90^{\circ} \mathrm{C}$ were considered to be heat resistant and were designated as MHRSA strains.

When a liquid or solid nutrient-rich medium, such as BHI medium, was used for the recovery and growth of the stressed S. aureus cells, the growth was found to be more efficient than by using other complex media or defined media, such as Baird-Parker agar, which was shown to cause a delay in cell growth. Similarly, milk components that are more nutritious would also be conducive for the growth of $S$. aureus cells as it is a dominant bacterium, which is found to be present in milk even after the heat treatment during pasteurization. However, the S. aureus strain ATCC 29737 did not grow after the heat treatment at 85 or $90^{\circ} \mathrm{C}$. Thus, the appearance of the heat-resistant strains may have been acquired through the use of temperatures higher than the heat treatment used during pasteurization, resulting in the formation of new proteins that helps these microbes to resist the elevated temperatures. In a study conducted by Kennedy et al. (2005), they determined the $\mathrm{D}$ values of $S$. aureus under pre-chilled storage conditions and storage conditions without pre-chilling, and found that the $\mathrm{D}_{50}, \mathrm{D}_{55}$, and $\mathrm{D}_{60}$ values ranged between 2,658-2,674 s, 780-1,302 s, and 288-390 s, respectively.

\section{CONCLUSIONS}

Pasteurized camel milk collected from different retail markets in Al-Riyadh, Saudi Arabia, was found to possess a high proportion of MHRSA (10\%). This prevalence was high in relation to the risk of this microbe and indicates a serious public health problem. Contamination of camel milk with this microbe is evidence of a potential threat that should be brought to the notice of the manufacturers of pasteurized camel milk because it lowers the quality and safety of the milk, thus affecting human consumers. Therefore, it is strongly suggested that the manufacturers should use different temperatures for milk processing, such as $93.8^{\circ} \mathrm{C}$ for $0.1 \mathrm{~s}, 96.2^{\circ} \mathrm{C}$ for $0.05 \mathrm{~s}$, or $100^{\circ} \mathrm{C}$ for $0.01 \mathrm{~s}$, to destroy the contaminating MHRSA.

\section{ACKNOWLEDGMENTS}

We extend our sincere appreciation to the Deanship of Scientific Research at King Saud University for funding this research through the Research Group project no. RG-1435-016. H.M.Y., A.H.A., K.M.A. and M.S.A. participated in the design of this study and carried out all the microbiology experiments. H.M.Y. wrote the paper and all the authors read and approved the final manuscript. The authors declare no conflict of interest.

\section{REFERENCES}

Al-Asmari, A. K., R. Abbasmanthiri, A. M. Al-Elawi, G. Al-Horaib, K. Al-Sadoon, and B. A. Al-Asmari. 2017. Effect of camel milk against renal toxicity in experimental rats. Pak. J. Pharm. Sci. 30:561-565.

Abdelgadir, W. S., T. K. Ahmed, and H. A. Dirar. 1998. The traditional fermented milk products of the Sudan. Int. J. Food Microbiol. 44:1-13. https://doi.org/10.1016/S0168-1605(98)00090-7. 
Al-Shabanah, O. A., M. M. Hafez, Z. K. Hassan, M. M. Sayed-Ahmed, W. N. Abozeed, S. S. Al-Rejaie, and A. A. Alsheikh. 2013. Human papillomavirus genotyping and integration in ovarian cancer Saudi patients. Virol. J. 10:343. https://doi.org/10.1186/1743-422X-10 -343 .

Ali, A. O., and H. Y. A. H. Mahmoud. 2017. Epidemiological studies based on multi-locus sequence typing genotype of methicillin susceptible Staphylococcus aureus isolated from camel's milk. Onderstepoort J. Vet. Res. 84:e1-e5. https://doi.org/10.4102/ojvr.v84i1 .1425 .

Ammendolia, M. G., R. Di Rosa, R. Montanaro, C. R. Arciola, and L. Baldassarri. 1999. Slime production and expression of the slimeassociated antigen by staphylococcal clinical isolates. J. Clin. Microbiol. 37:3235-3238. https://doi.org/10.1128/JCM.37.10.3235 $-3238.1999$.

Arab, H. H., S. A. Salama, T. M. Abdelghany, H. A. Omar, E. A. Arafa, M. M. Alrobaian, and I. A. Maghrabi. 2017. Camel milk attenuates rheumatoid arthritis via inhibition of mitogen activated protein kinase pathway. Cell. Physiol. Biochem. 43:540-552. https: //doi.org/10.1159/000480527.

Arsic, B., Y. Zhu, D. E. Heinrichs, and M. J. McGavin. 2012. Induction of the Staphylococcal proteolytic cascade by antimicrobial fatty acids in community acquired methicillin resistant Staphylococcus aureus. PLoS One 7:e45952. https://doi.org/10.1371/ journal.pone.0045952.

Ayyash, M., A. S. Al-Dhaheri, S. Al-Mahadin, J. Kizhakkayil, and A. Abushelaibi. 2018. In vitro investigation of anticancer, antihypertensive, antidiabetic, and antioxidant activities of camel milk fermented with camel milk probiotic: A comparative study with fermented bovine milk. J. Dairy Sci. 101:900-911. https://doi.org/ $10.3168 /$ jds. 2017-13400.

Bal, A. M., G. W. Coombs, M. T. Holden, J. A. Lindsay, G. R. Nimmo, P. Tattevin, and R. L. Skov. 2016. Genomic insights into the emergence and spread of international clones of healthcare-, community-and livestock-associated methicillin-resistant Staphylococcus aureus: Blurring of the traditional definitions. J. Glob. Antimicrob. Resist. 6:95-101. https://doi.org/10.1016/j.jgar.2016.04.004.

Baron, S. 1996. Medical Microbiology, 4th ed. University of Texas Medical Branch at Galveston, Galveston, TX.

Brakstad, O. G., Y. Tveten, F. Nato, and J. M. Fournier. 1993. Comparison of various methods and reagents for species identification of Staphylococcus aureus positive or negative for the mecA gene. APMIS 101:651-654. https://doi.org/10.1111/j.1699-0463.1993 .tb00160.x.

Brown, D. F., D. I. Edwards, P. M. Hawkey, D. Morrison, G. L. Ridgway, K. J. Towner, and M. W. Wren. 2005. Joint Working Party of the British Society for Antimicrobial Chemotherapy; Hospital Infection Society and Infection Control Nurses Association. Guidelines for the laboratory diagnosis and susceptibility testing of methicillin-resistant Staphylococcus aureus (MRSA). J. Antimicrob. Chemother. 56:1000-1018. https://doi.org/10.1093/jac/ dki372.

Buffo, R. A., and R. A. Holley. 2006. Effects of food processing on disease agents. Page 716 in Food Borne Infections and Intoxications. 3rd ed. H. P. Riemann and D. O. Cliver, ed. Elsevier Academic Press.

Caputy, G. C., and J. W. Costerton. 1984. Immunological examination of the glycocalyces of Staphylococcus aureus strains Wiley and Smith. Curr. Microbiol. 11:297-302. https://doi.org/10.1007/ BF01567390.

Caputy, G. G., and J. W. Costerton. 1982. Morphological examination of the glycocalyses of Staphylococcus aureus strains. Infect. Immun. 36:759-767. https://doi.org/10.1128/IAI.36.2.759-767.1982.

Cardoso, R. R., M. Ponte, and V. Leite. 2013. Protective action of camel milk in mice inoculated with Salmonella enterica. Isr. Med. Assoc. J. 15:5-8.

Chen, H. Y., O. Mollstedt, M. H. Tsai, and R. B. Kreider. 2014. Potential clinical applications of multi-functional milk proteins and peptides in cancer management. Curr. Med. Chem. 21:2424-2437. https://doi.org/10.2174/0929867321666140205135739.
Christensen, G. D., W. A. Simpson, A. L. Bisno, and E. H. Beachey. 1982. Adherence of slime producing strains of Staphylococcus epidermidis to smooth surfaces. Infect. Immun. 37:318-326. https:// doi.org/10.1128/IAI.37.1.318-326.1982.

Clinical and Laboratory Standards Institute (CLSI). 2018. Performance standards for antimicrobial susceptibility testing; 27 th informational supplement. M100-S28. Clinical and Laboratory Standards Institute, Wayne, PA.

Cosgrove, S. E., G. Sakoulas, E. N. Perencevich, M. J. Schwaber, A. W. Karchmer, and Y. Carmeli. 2003. Comparison of mortality associated with methicillin-resistant and methicillin-susceptible Staphylococcus aureus bacteremia: A meta-analysis. Clin. Infect. Dis. 36:53-59. https://doi.org/10.1086/345476.

Cremer, A. W., and R. N. Gruneberg. 1988. Assessment of a new test $\left(\right.$ Staphylase $^{\mathrm{TM}}$ ) for the identification of Staphylococcus aureus. Med. Lab. Sci. 45:221-224.

Davenport, D. S., R. M. Massanari, M. A. Pfaller, M. J. Bale, S. A. Streed, and W. J. Hierholzer. 1986. Usefulness of a test for slime production as a marker for clinically significant infections with coagulase negative Staphylococci. J. Infect. Dis. 153:332-339. https:/ /doi.org/10.1093/infdis/153.2.332.

Davies, S. 1997. Detection of methicillin-resistant Staphylococcus aureus: The evaluation of rapid agglutination methods. Br. J. Biomed. Sci. 54:13-15.

Di Salvo, J. W. 1958. Deoxyribonuclease and coagulase activity of micrococci. Med. Tech. Bull. U. S. Armed Forces Med. J. 9:191.

Diaz-Mitoma, F., G. K. M. Harding, D. J. Hoban, R. S. Roberts, and D. E. Low. 1987. Clinical significance of a test for slime production in ventriculoperitoneal shunt infections caused by coagulase negative staphylococci. J. Infect. Dis. 156:555-560. https://doi.org/10 .1093/infdis/156.4.555.

Ebaid, H., B. Abdel-Salam, I. Hassan, J. Al-Tamimi, A. Metwalli, and I. Alhazza. 2017. Erratum to: camel milk peptide improves wound healing in diabetic rats by orchestrating the redox status and immune response. Lipids Health Dis. 16:43. https://doi.org/10.1186/ s12944-017-0421-x.

Ehlayel, M. S., K. A. Hazeima, F. Al-Mesaifri, and A. Bener. 2011. Camel milk: An alternative for cow's milk allergy in children. Allergy Asthma Proc. 32:255-258. https://doi.org/10.2500/aap.2011 .32 .3429 .

El-Agamy, E. I., R. Ruppanner, A. Ismail, C. P. Champagne, and R. Assaf. 1992. Antibacterial and antiviral activity of camel milk protective proteins. J. Dairy Res. 59:169-175. https://doi.org/10 $.1017 /$ S0022029900030417.

El-Fakharany, E. M., N. A. El-Baky, M. H. Linjawi, A. A. Aljaddawi, T. H. Saleem, A. Y. Nassar, A. Osman, and E. M. Redwan. 2017. Influence of camel milk on the hepatitis $\mathrm{C}$ virus burden of infected patients. Exp. Ther. Med. 13:1313-1320. https://doi.org/10.3892/ etm.2017.4159.

Etienne, J., Y. Brun, N. el Solh, V. Delorme, C. Mouren, M. Bes, and J. Fleurette. 1988. Characterization of clinically significant isolates of Staphylococcus epidermidis from patients with endocarditis. J. Clin. Microbiol. 26:613-617. https://doi.org/10.1128/JCM.26.4 .613-617.1988.

FDA (US Food and Drug Administration). 2011. Grade "A", Pasteurized Milk Ordinance, 2007 revision. US Department of Health and Human Services Public Health Service. Accessed Sep. 12 2013. http://www.fda.gov/downloads/Food/GuidanceRegulation/ UCM291757.pdf.

Felten, A., B. Grandry, B. H. Lagrange, and I. Casin. 2002. Evaluation of three techniques for detection of low-level methicillin-resistant Staphylococcus aureus (MRSA): A disk diffusion method with cefoxitin and moxalactam, the Vitek 2 system, and the MRSA screen latex agglutination test. J. Clin. Microbiol. 40:2766-2771. https://doi.org/10.1128/JCM.40.8.2766-2771.2002.

Founou, L. L., R. C. Founou, and S. Y. Essack. 2016. Antibiotic resistance in the food chain: A developing country perspective. Front. Microbiol. 7:1881. https://doi.org/10.3389/fmicb.2016.01881.

Fournier, J. M., A. Bouvet, D. Mathieu, F. Nato, A. Boutonnier, R. Gerbal, P. Brunengo, C. Saulnier, N. Sagot, B. Slizewicz, and J. 
C. Mazie. 1993. New latex reagent using monoclonal antibodies to capsular polysaccharide for reliable identification of both oxacillinsusceptible and oxacillin-resistant Staphylococcus aureus. J. Clin. Microbiol. 31:1342-1344. https://doi.org/10.1128/JCM.31.5.1342 $-1344.1993$.

Fridkin, S. K., J. Hageman, L. K. McDougal, J. Mohammed, W. R. Jarvis, T. M. Perl, and F. C. Tenover, and Vancomycin-Intermediate Staphylococcus aureus Epidemiology Study Group. 2003 Epidemiological and microbiological characterization of infections caused by Staphylococcus aureus with reduced susceptibility to vancomycin. United States, 1997-2001. Clin. Infect. Dis. 36:429439. https://doi.org/10.1086/346207.

Georgopapadakou, N. H., B. A. Dix, and Y. R. Mauriz. 1986. Possible physiological functions of penicillin-binding proteins in Staphylococcus aureus. Antimicrob. Agents Chemother. 29:333-336. https: //doi.org/10.1128/AAC.29.2.333.

Haddadin, A. S., S. A. Fappiano, and P. A. Lipsett. 2002. Methicillinresistant Staphylococcus aureus (MRSA) in the intensive care unit. Postgrad. Med. J. 78:385-392. https://doi.org/10.1136/pmj.78.921 .385 .

Hailu, Y., E. B. Hansen, E. Seifu, M. Eshetu, and R. Ipsen. 2016. Factors influencing the gelation and rennetability of camel milk using camel chymosin. Int. Dairy J. 60:62-69. https://doi.org/10.1016/ j.idairyj.2016.01.013.

Hiramatsu, K. 1995. Molecular evolution of MRSA. Microbiol. Immunol. 39:531-543. https://doi.org/10.1111/j.1348-0421.1995 tb02239.x.

Holdsworth, S. D. 1997. Pages 70-111 in Thermal Processing of Packaged Foods. Blackie Academic and Professional, London, UK. https://doi.org/10.1002/food.19970410527.

Hsueh, P. R., L. J. Teng, P. C. Yang, H. J. Pan, Y. C. Chen, L. H. Wang, S. W. Ho, and K. T. Luh. 1999. Dissemination of two methicillin-resistant Staphylococcus aureus clones exhibiting negative staphylase reactions in intensive care units. J. Clin. Microbiol. 37:504-509. https://doi.org/10.1128/JCM.37.3.504-509.1999.

International Standard Office, 2003. Microbiology of food and animal feeding stuffs - horizontal method for the enumeration of coagulase-positive staphylococci, EN ISO 6888-1 (Staphylococcus aureus and other species).

Ishak, M. A., D. H. Groschel, G. L. Mandell, and R. P. Wenzel. 1985. Association of slime with pathogenicity of coagulase-negative Staphylococci causing nosocomial septicemia. J. Clin. Microbiol. 22:1025-1029. https://doi.org/10.1128/JCM.22.6.1025-1029.1985.

Jevons, M. P., A. W. Coe, and M. T. Parker. 1963. Methicillin resistance in Staphylococci. Lancet 281:904-907. https://doi.org/10 .1016/S0140-6736(63)91687-8.

Kennedy, J., V. Jackson, I. S. Blair, D. A. McDowell, C. Cowan, and D. J. Bolton. 2005. Consumers food safety knowledge and the microbiological and temperature status of their refrigerators. J. Food Prot. 68:1421-1430. https://doi.org/10.4315/0362-028X-68 .7 .1421$.

Khan, M. A. 2017. Immune potentiating and antitoxic effects of camel milk against cyclophosphamide-induced toxicity in BALB/C mice. Int. J. Health Sci. (Qassim) 11:18-22.

Kleeman, K. T., T. L. Bannerman, and W. E. Kloos. 1993. Species distribution of coagulase-negative Staphylococcal isolates at a community hospital and implications for selection of Staphylococcal identification procedures. J. Clin. Microbiol. 31:1318-1321. https:/ /doi.org/10.1128/JCM.31.5.1318-1321.1993.

Kloos, W. E., and T. L. Bannerman. 1995. Staphylococcus and Micrococcus. Pages 282-298 in Manual of Clinical Microbiology, 6th ed. P. R. Murray, E. J. Baron, M. A. Pfaller, F. C. Tenover, and R. H. Yolken, ed. ASM Press, Washington, DC.

Kloos, W. E., and T. L. Bannerman. 1994. Update on clinical significance of coagulase-negative Staphylococci. Clin. Microbiol. Rev. 7:117-140. https://doi.org/10.1128/CMR.7.1.117.

Korashy, H. M., Z. H. Maayah, A. R. Abd-Allah, A. O. El-Kadi, and A. A. Alhaider. 2012. Camel milk triggers apoptotic signaling pathways in human hepatoma HepG2 and breast cancer MCF7 cell lines through transcriptional mechanism. J. Biomed. Biotechnol. 2012:1. https://doi.org/10.1155/2012/593195.
Korish, A. A. 2014. The antidiabetic action of camel milk in experimental type 2 diabetes mellitus: An overview on the changes in incretin hormones, insulin resistance, and inflammatory cytokines. Horm. Metab. Res. 46:404-411. https://doi.org/10.1055/s-0034 $-1368711$.

Korish, A. A., A. G. Abdel Gader, H. M. Korashy, A. M. Al-Drees, A. A. Alhaider, and M. M. Arafah. 2015. Camel milk attenuates the biochemical and morphological features of diabetic nephropathy: Inhibition of Smad1 and collagen type IV synthesis. Chem. Biol Interact. 229:100-108. https://doi.org/10.1016/j.cbi.2015.01.013.

Kouidhi, B., T. Zmantar, H. Hentati, and A. Bakhrouf. 2010. Cell surface hydrophobicity, biofilm formation, adhesives properties and molecular detection of adhesins genes in Staphylococcus aureus associated to dental caries. Microb. Pathog. 49:14-22. https://doi .org/10.1016/j.micpath.2010.03.007.

Kuikka, A., and V. V. Valtonen. 1994. Improved outcomes of Staphylococcus aureus bacteremia. Infect. Dis. Clin. Pract. 3:282-287. https://doi.org/10.1097/00019048-199407000-00009.

Lee, G.-H., B.-H. Tan, E. Chi-Yuan Teo, S.-G. Lim, Y.-Y. Dan, A. Wee, P. P. Kim Aw, Y. Zhu, M. L. Hibberd, C.-K. Tan, M. A. Purdy, and C.-G. Teo. 2016. Chronic infection with camelid hepatitis $\mathrm{E}$ virus in a liver transplant recipient who regularly consumes camel meat and milk. Gastroenterology 150:355-357. https://doi .org/10.1053/j.gastro.2015.10.048.

Lim, S. K., H. M. Nam, G. C. Jang, H. S. Lee, S. C. Jung, and T. S. Kim. 2013. Transmission and persistence of methicillin-resistant Staphylococcus aureus in milk, environment, and workers in dairy cattle farms. Foodborne Pathog. Dis. 10:731e736.

Mack, K. D., S. Bartscht, M. A. Dobinsky, H. Horskotte, K. M. Kiel, A. Knobloch, and P. Schafer. 2000. Staphylococcal factors involved in adhesion and biofilm formation on biomaterials. Pages 307330 in Handbook of Bacterial Adhesion. Principles Methods and Applications. Y. H. An and R. J. Friedman, ed. Humana Press, Totowa, NJ.

Macori, G., G. Giacinti, A. Bellio, S. Gallina, D. M. Bianchi, D. Sagrafoli, N. Marri, G. Giangolini, S. Amatiste, and L. Decastelli. 2017. Molecular epidemiology of methicillin-resistant and methicillin-susceptible Staphylococcus aureus in the ovine dairy chain and in farm-related humans. Toxins (Basel) 9:161. https://doi.org/10 $.3390 /$ toxins 9050161

Martineau, F., F. J. Picard, P. H. Roy, M. Ouellette, and M. G. Bergeron. 1998. Species-specific and ubiquitous-DNA-based assays for rapid identification of Staphylococcus aureus. J. Clin. Microbiol. 36:618-623. https://doi.org/10.1128/JCM.36.3.618-623.1998.

Mihic, T., D. Rainkie, K. J. Wilby, and S. A. Pawluk. 2016. The therapeutic effects of camel milk: A systematic review of animal and human trials. J. Evid. Based Complem. Altern. Med. 21:NP110NP126.

Mirmiran, P., H. S. Ejtahed, P. Angoorani, F. Eslami, and F. Azizi. 2017. Camel milk has beneficial effects on diabetes mellitus: A systematic review. Int. J. Endocrinol. Metab. 15:e42150. https:// doi.org/10.5812/ijem.42150.

Moon, J. S., A. R. Lee, H. M. Kang, E. S. Lee, M. N. Kim, Y. H. Paik, Y. H. Park, Y. S. Joo, and H. C. Koo. 2007. Phenotypic and genetic antibiogram of methicillin-resistant staphylococci isolated from bovine mastitis in Korea. J. Dairy Sci. 90:1176e1185.

Nakazawa, H., Y. Kikuchi, T. Honda, T. Isago, and M. Nozaki. 2003. Enhancement of antimicrobial effects of various antibiotics against methicillin-resistant Staphylococcus aureus (MRSA) by combination with fosfomycin. J. Infect. Chemother. 9:304-309. https://doi .org/10.1007/s10156-003-0266-2.

Nam, H. M., A. R. Lee, S. C. Jung, M. N. Kim, G. C. Jang, S. H. Wee, and S. K. Lim. 2011. Antimicrobial susceptibility of Staphylococcus aureus and characterization of methicillin-resistant Staphylococcus aureus isolated from bovine mastitis in Korea. Foodborne Pathog. Dis. 8:231e238.

Niemeyer, D. M., M. J. Pucci, J. A. Thanassi, V. K. Sharma, and G. L. Archer. 1996. Role of $m e c A$ transcriptional regulation in the phenotypic expression of methicillin resistance in Staphylococcus aureus. J. Bacteriol. 178:5464-5471. https://doi.org/10.1128/JB $.178 .18 .5464-5471.1996$. 
Ogata, K., H. Narimatsu, M. Suzuki, W. Higuchi, T. Yamamoto, and H. Taniguchi. 2012. Commercially distributed meat as a potential vehicle for community-acquired methicillin-resistant Staphylococcus aureus. Appl. Environ. Microbiol. 78:2797-2802. https://doi .org/10.1128/AEM.07470-11.

Otto, M. 2014. Staphylococcus aureus toxins. Curr. Opin. Microbiol. 17:32-7. https://doi.org/10.1016/j.mib.2013.11.004.

Paterson, G. K., E. M. Harrison, and M. A. Holmes. 2014. The emergence of mecA methicillin-resistant Staphylococcus aureus. Trends Microbiol. 22:42-47. https://doi.org/10.1016/j.tim.2013.11.003.

Piper, J., T. Hadfield, F. McCleskey, M. Evans, S. Friedstrom, P. Lauderdale, and R. Winn. 1988. Efficacies of rapid agglutination tests for identification of methicillin-resistant staphylococcal strains as Staphylococcus aureus. J. Clin. Microbiol. 26:1907-1909. https:// doi.org/10.1128/JCM.26.9.1907-1909.1988.

$\mathrm{Pu}, \mathrm{S} ., \mathrm{F}$. Han, and B. Ge. 2009. Isolation and characterization of methicillin resistant Staphylococcus aureus strains from Louisiana retail meats. Appl. Environ. Microbiol. 75:265-267. https://doi .org/10.1128/AEM.01110-08.

Rahimi, E., and E. K. Kheirabadi. 2012. Detection of Helicobacter pylori in bovine, buffalo, camel, ovine, and caprine milk in Iran. Foodborne Pathog. Dis. 9:453-456. https://doi.org/10.1089/fpd .2011 .1060 .

Rodríguez-Lázaro, D., J. Ariza-Miguel, M. Diez-Valcarce, I. Fernández-Natal, M. Hernández, and J. Rovira. 2015. Foods confiscated from non-EU flights as a neglected route of potential methicillinresistant Staphylococcus aureus transmission. Int. J. Food Microbiol. 209:29-33. https://doi.org/10.1016/j.ijfoodmicro.2014.08.016.

Rodríguez-Lázaro, D., E. A. Oniciuc, P. G. García, D. Gallego, I Fernández-Natal, M. Dominguez-Gil, J. M. Eiros-Bouza, M. Wagner, A. I. Nicolau, and M. Hernández. 2017. Detection and characterization of Staphylococcus aureus and methicillin-resistant S. aureus in foods confiscated in EU borders. Front. Microbiol. 8:1344. https://doi.org/10.3389/fmicb.2017.01344.

Ruane, P. J., M. A. Morgan, D. M. Citron, and M. E. Mulligan. 1986. Failure of rapid agglutination methods to detect oxacillin-resistant Staphylococcus aureus. J. Clin. Microbiol. 24:490-492. https://doi .org/10.1128/JCM.24.3.490-492.1986.

Rubin, R. J., C. A. Harrington, A. Poon, K. Dietrich, J. A. Greene, and A. Moiduddin. 1999. The economic impact of Staphylococcus aureus infection in New York City hospitals. Emerg. Infect. Dis. 5:9-17. https://doi.org/10.3201/eid0501.990102.

Rupp, M. E., and G. D. Archer. 1994. Coagulase-negative Staphylococci: Pathogens associated with medical progress. Clin. Infect. Dis. 19:231-245. https://doi.org/10.1093/clinids/19.2.231.

Scarcelli, E., E. O. Costa, M. É. Genovez, M. V. Cardoso, E. E. Bach, and A. P. Torres. 2001. Comparison of electrophoretic protein profiles of Campylobacter jejuni ssp. jejuni isolated from different animal species. Braz. J. Microbiol. 32:286-292. https://doi.org/10 $.1590 / \mathrm{S} 1517-83822001000400006$.

Schwarzkopf, A. 1995. Coagulase gene polymorphism in Staphylococcus aureus - A new epidemiological marker. Immun. Infekt. 23:9-14.

Shori, A. B. 2015. Camel milk as a potential therapy for controlling diabetes and its complications: A review of in vivo studies. Yao $\mathrm{Wu}$ Shi Pin Fen Xi 23:609-618. https://doi.org/10.1016/j.jfda.2015.02 .007 .

Simonetti, O., G. Morroni, R. Ghiselli, F. Orlando, A. Brenciani, L. Xhuvelaj, M. Provinciali, A. Offidani, M. Guerrieri, A. Giacometti, and O. Cirioni. 2018. In vitro and in vivo activity of fosfomycin alone and in combination with rifampin and tigecycline against Grampositive cocci isolated from surgical wound infections. J. Med. Microbiol. 67:139-143. https://www.microbiologyresearch .org/docserver/fulltext/jmm/67/1/139_jmm000649.pdf ?expires $=1587110879 \& \mathrm{id}=\mathrm{id} \&$ accname $=$ guest $\&$ checksum $=$ B4D7821E10282F97BEFABAD340B49D63.

Skov, R., R. Smyth, M. Clausen, A. R. Larsen, N. Frimodt-Moller, B. Olsson-Liljequist, and G. Kahlmeter. 2003. Evaluation of a cefoxitin $30 \mu \mathrm{g}$ disc on Iso-Sensitest agar for detection of methicillin-resistant Staphylococcus aureus. J. Antimicrob. Chemother. 52:204-207. https://doi.org/10.1093/jac/dkg325.

Soliman, M. M., M. Y. Hassan, S. A. Mostafa, H. A. Ali, and O. M. Saleh. 2015. Protective effects of camel milk against pathogenicity induced by Escherichia coli and Staphylococcus aureus in Wistar rats. Mol. Med. Rep. 12:8306-8312. https://doi.org/10.3892/mmr .2015.4486.

Song, J. W., S. J. Yang, S. Shin, K. S. Seo, Y. H. Park, and K. T. Park. 2016. Genotypic and phenotypic characterization of methicillin-resistant Staphylococcus aureus isolated from bovine mastitic milk in Korea. J. Food Prot. 79:1725-1732. https://doi.org/10 .4315/0362-028X.JFP-16-067.

Stephenson, J. R., S. J. Crook, and S. Tabaqchali. 1986. New method for typing Staphylococcus aureus resistant to methicillin based on sulphur-35 methionine labelled proteins: Its application in an outbreak. Br. Med. J. (Clin. Res. Ed.) 293:581-583. https://doi.org/ 10.1136/bmj.293.6547.581.

Swenson, J. M., D. Lonsway, S. McAllister, A. Thompson, L. Jevitt, W. Zhu, and J. B. Patel. 2007. Detection of mecA-mediated resistance using reference and commercial testing methods in a collection of Staphylococcus aureus expressing borderline oxacillin MICs. Diagn. Microbiol. Infect. Dis. 58:33-39. https://doi.org/10.1016/j .diagmicrobio.2006.10.022.

Swenson, J. M., and F. C. Tenover. 2005. Results of disk diffusion testing with cefoxitin correlate with presence of mecA in Staphylococcus spp. J. Clin. Microbiol. 43:3818-3823. https://doi.org/10 .1128/JCM.43.8.3818-3823.2005.

Voss, A., F. Loeffen, J. Bakker, C. Klaassen, and M. Wulf. 2005. Methicillin-resistant Staphylococcus aureus in pig farming. Emerg. Infect. Dis. 11:1965-1966. https://doi.org/10.3201/eid1112.050428.

Weese, J. S., B. P. Avery, and R. J. Reid-Smith. 2010. Detection and quantification of methicillin-resistant Staphylococcus aureus (MRSA) clones in retail meat products. Lett. Appl. Microbiol. 51:338-342. https://doi.org/10.1111/j.1472-765X.2010.02901.x.

Weist, K., A. Cimbal, C. Lecke, G. Fight, H. Males, and R. Vonberg. 2006. Evaluation of six agglutination tests for Staphylococcus aureus identification depending upon local prevalence of methicillinresistant S. aureus (MRSA). J. Med. Microbiol. 55:283-290. https: //doi.org/10.1099/jmm.0.46225-0.

Yehia, H. M., and M. M. Al-Dagal. 2014. Prevalence of Campylobacter jejuni in chicken produced by major poultry companies in Saudi Arabia. Int. J. Food Contam. 1:2. https://doi.org/10.1186/s40550 $-014-0002-y$.

Yehia, H. M., E. A. Ismail, Z. K. Hassan, A. H. Al-masoud, and M. M. Al-Dagal. 2019. Heat resistance and presence of genes encoding staphylococcal enterotoxins evaluated by multiplex-PCR of Staphylococcus aureus isolated from pasteurized camel milk. Biosci. Rep. 39:BSR20191225. https://doi.org/10.1042/BSR20191225.

Zervosen, A., E. Sauvage, J. M. Frere, P. Charlier, and A. Luxen. 2012 Development of new drugs for an old target - The penicillin binding proteins. Molecules 17:12478-12505. https://doi.org/10.3390/ molecules171112478.

Zhou, Y. P., A. Wilder-Smith, and L. Y. Hsu. 2014. The role of international travel in the spread of methicillin-resistant Staphylococcus aureus. J. Travel Med. 21:272-281. https://doi.org/10.1111/jtm .12133

Zibaee, S., S. M. Hosseini, M. Yousefi, A. Taghipour, M. A. Kiani, and M. R. Noras. 2015. Nutritional and therapeutic characteristics of camel milk in children: A systematic review. Electron. Physician 7:1523-1528. https://doi.org/10.19082/1523.

\section{ORCIDS}

Hany M. Yehia (1) https://orcid.org/0000-0001-5387-8026 Khaloud M. Alarjani 으 https://orcid.org/0000-0002-3762-1498 